\title{
The significance of mudstone fabric combined with palaeoecological evidence in determining sedimentary processes - an example from the Middle Jurassic of southern Poland
}

\author{
Paulina LEONOWICZ ${ }^{1, *}$ \\ 1 Institute of Geology, University of Warsaw, Żwirki i Wigury 93, 02-089 Warszawa, Poland
}

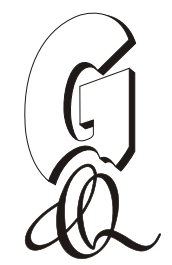

\begin{abstract}
Leonowicz P. (2013) The significance of mudstone fabric combined with palaeoecological evidence in determining sedimentary processes - an example from the Middle Jurassic of southern Poland. Geological Quarterly, 57 (2): 243-260, doi: 10.7306/gq.1092

Analysis of the fabric of laminated black mudstones of the Ore-Bearing Częstochowa Clay Formation (Bathonian, southern Poland) is used for reconstruction of sedimentary processes and conditions. Small-scale sedimentary features indicate that ore-bearing clays were deposited below storm-wave base in a shallow epicontinental sea, but structures reflecting quiet settling from suspension are not common. Most of recognized lamina types record the activity of bottom currents generated by storms. The benthic faunal association indicates that suboxic conditions prevailed on the sea-floor, restricting infaunal activity to cryptobioturbation. Recurrent short-lived reoxygenetion events, linked probably to storms, resulted in the development of dysoxic conditions, recorded by a more diverse trace fossil association (consisting of Chondrites, Trichichnus, pyritized burrows, Palaeophycus and Protovirgularia) and colonization of the sea-floor by epifaunal bivalves (Bositra). Truly anoxic conditions might have been briefly established, leading to mass mortality of Bositra.
\end{abstract}

Key words: black mudstones, parallel lamination, storm deposits, ichnofabric, bottom oxygenation, Ore-Bearing Częstochowa Clay Formation.

\section{INTRODUCTION}

Middle Jurassic black mudstones in southern Poland, referred to as the Ore-Bearing Częstochowa Clay Formation, have recently received increasing interest as regards their palaeoecology. The sedimentary environment of these dark, organic-rich rocks that are for the most part strongly bioturbated and rich in diverse benthic fauna still inspires study. In contrast to the growing volume of literature on this deposit (for summary see Zatoń et al., 2009; Zatoń, 2011), sedimentological studies remain scarce (Merta and Drewniak, 1998; Gedl et al. 2006a, b, C; Leonowicz, 2012) and understanding of the sedimentary processes, which largely determined bottom conditions, has been poor. This study integrates microstructural and ichnofabric analysis in reconstructing sedimentary processes, environmental energy and palaeoecology of the sea-floor. It focuses on laminated mudstones of the Ore-Bearing Częstochowa Clay Formation, cropping out in the central part of the Silesian-Cracow Upland in southern Poland (Fig. 1).

The Ore-Bearing Częstochowa Clay Formation is composed of dark grey, organic-rich, calcareous mudstone with

\footnotetext{
* E-mail address: Paulina.Leonowicz@uw.edu.pl
}

Received: July 17, 2012; accepted: December 7, 2012; first published online: May 14, 2013 several horizons of siderite and calcareous concretions, clayey siderite bands and subordinate intercalations of sandstone (Dayczak-Calikowska and Kopik, 1973). The greater part is strongly bioturbated and rich in diverse benthic fossils; laminated, sparsely fossiliferous mudstones are much less common. Geochemical and petrographical studies point to deposition on a well-oxygenated sea-floor with simultaneously dysoxic or even anoxic conditions prevailing within the sediment (Marynowski et al., 2007; Szczepanik et al., 2007; Zatoń et al., 2009). They do not reveal significant fluctuation within the succession, suggesting stable redox conditions. No evidence of anoxia or water column stratification was found. Merta and Drewniak (1998) defined the environment of deposition as a marine basin with quiet or even stagnant waters and a slow rate of deposition. According to them, sediment was derived in the form of suspension clouds by storm-induced low-energy bottom currents. They interpreted the environment as an open basin or estuary. Gedl et al. (2006a, b, c) and Leonowicz (2012) also suggested quiet marine conditions, below storm-wave base and interrupted by high-energy storm episodes, generating offshore currents. Although these studies have significantly improved knowledge of depositional processes, they are to a high degree speculative as they are based on strongly bioturbated deposits, in which only indistinct relicts of primary sedimentary structures are preserved. Other generalized interpretations of the sedimentary environment of the ore-bearing clays arose from the analysis of microfauna or of particular horizons of siderite concretions. Garbowska et al. (1978) and Smoleń (2006) characterized the depositional setting generally as shallow to 


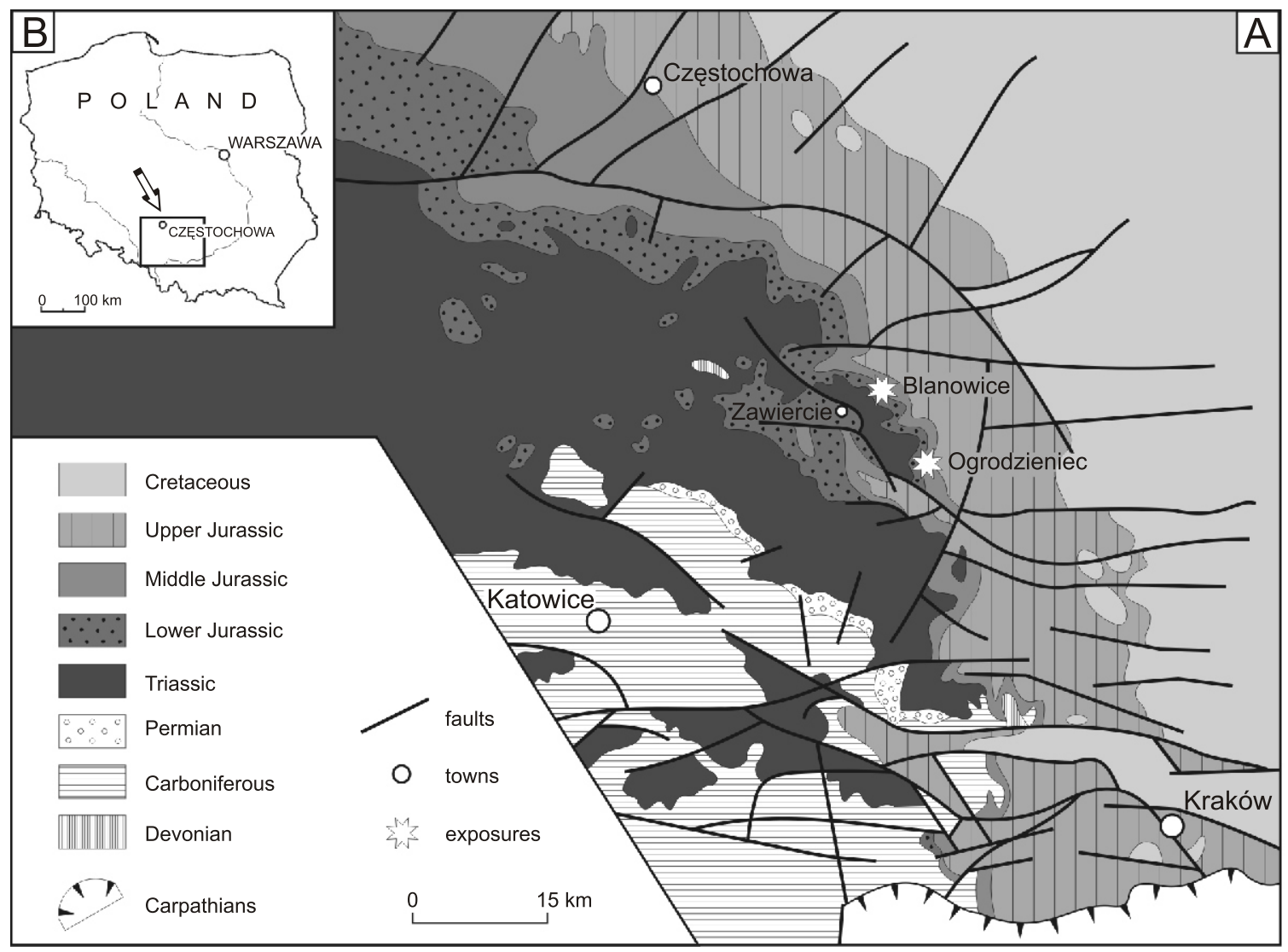

Fig. 1A - geological map of the Silesian-Cracow Upland (after Dadlez et al., 2000, simplified) and location of the sections studied; B - location of the area shown on A (arrowed)

very shallow marine, intermittently affected by high-energy events. Similarly, Zatoń et al. (2011) described horizons of hiatus concretions and linked their origin with a shallow, high-energy subtidal environment.

This paper provides evidence that generally supports previous interpretations of the sedimentary environment for the Ore-Bearing Częstochowa Clay Formation, but indicates much more important role of bottom currents in mudstone deposition than has been previously considered. This underlines the utility of microstructural analysis in determining sedimentary processes and shows that shale fabric analysis combined with palaeoecological evidence may serve as an efficient tool in studying fine-grained rocks.

\section{GEOLOGICAL SETTING}

The Ore-Bearing Częstochowa Clay Formation constitutes the main part of the Middle Jurassic succession in the Silesian-Cracow Upland. It was deposited in a shallow epicontinental sea, termed the Polish Basin (Fig. 2A; Dadlez, 1989), which was the easternmost arm of the Central European Basin System (CEBS; Pieńkowski et al., 2008). During the Jurassic, the Polish Basin was surrounded from the north-east, east and south-west by land (Fig. 2A), which served as a source area for clastic material (Dadlez, 1989; Feldman-Olszewska, 1997; Marynowski et al., 2007). In the south it was separated from the Tethyan domain by the Meta-Carpathian Arc (Kutek, 1994), whereas to the north-west and south-east the Polish Basin was connected temporarily with the CEBS and the Tethys.
Through these gateways marine transgressions developed. Deposition of the Middle Jurassic succession in Poland was linked with a marine transgression in the Polish Basin during the Aalenian (Dayczak-Calikowska and Moryc, 1988) that most probably came from the south-east (Dayczak-Calikowska, 1997; Pieńkowski et al., 2008) and continued during the Late Jurassic. The complete and thickest succession, exceeding $1000 \mathrm{~m}$, was deposited in the Mid-Polish Trough that represented a NW-SE oriented axial zone (Fig. 2B), characterized by maximum subsidence (Dayczak-Calikowska and Moryc, 1988; Feldman-Olszewska, 1997). Outside this zone the sequence is only up to $300 \mathrm{~m}$ thick and reveals sedimentary hiatuses, resulting from second order sea level falls (DayczakCalikowska and Moryc, 1988; Feldman-Olszewska, 1997; Pieńkowski et al., 2008).

The Silesian-Cracow area was situated in the southwestern, marginal part of the Polish Basin (Fig. 2B). The Middle Jurassic succession starts here with Lower Bajocian (sauzei-humphriesianum zones) sandy deposits of the Kościelisko Beds (Fig. 3), which rest with a stratigraphic hiatus on older Mesozoic rocks (Kopik, 1997, 1998). The Kościelisko Beds are overlain by a thick muddy succession that is Late Bajocian to Late Bathonian in age (garantiana-discus zones), which represents the Ore-Bearing Częstochowa Clay Formation (Fig. 3), commonly referred to as ore-bearing clays (Kopik, 1998; Matyja and Wierzbowski, 2000; Barski et al., 2004). This, in turn, is capped by condensed Callovian deposits, represented by limestones, sandstones and marls (Kopik, 1997).

The Ore-Bearing Częstochowa Clay Formation crops out in the Silesian-Cracow Upland in a narrow belt, extending from north-west to south-east, and wedging out near the town of 


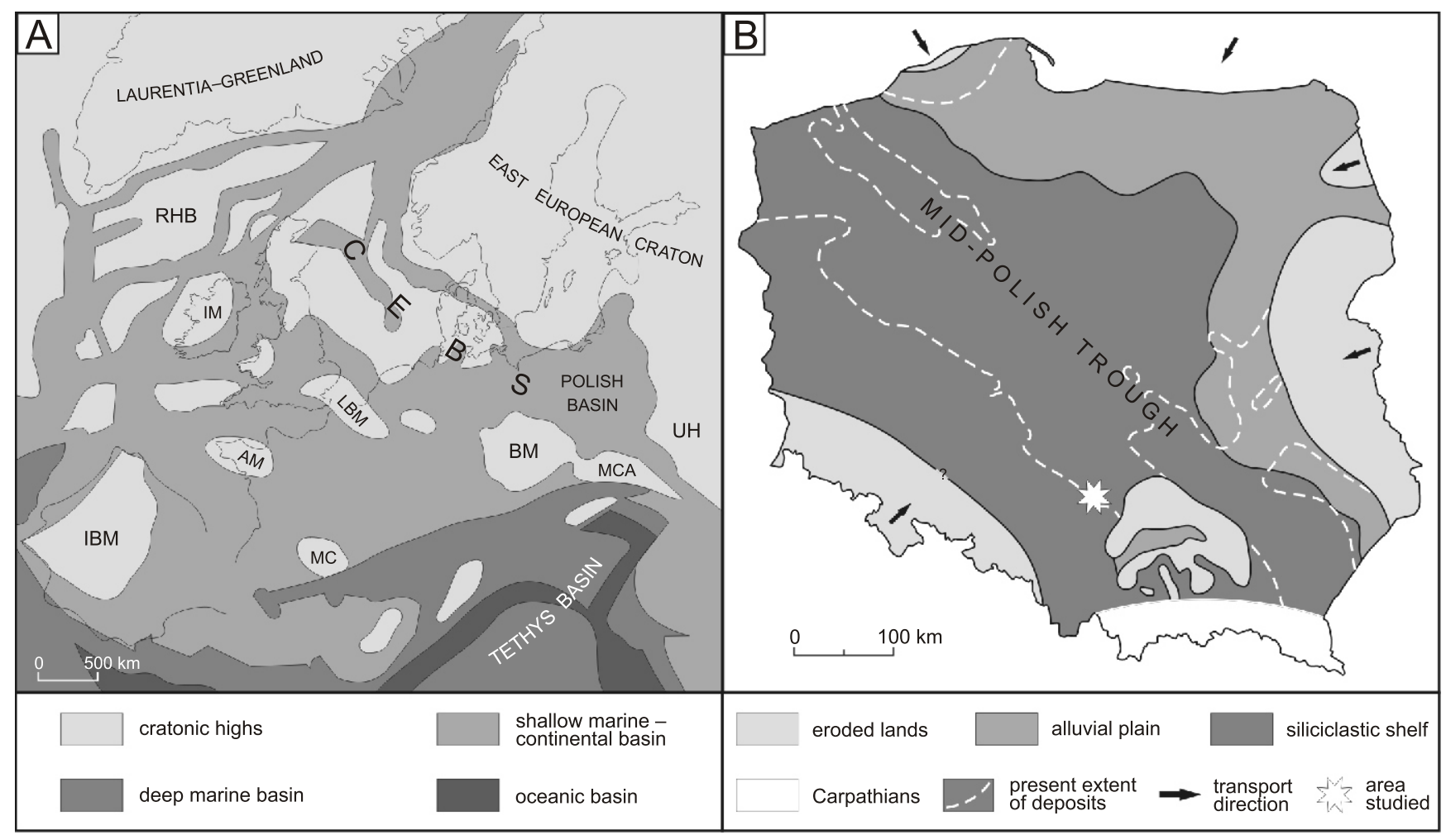

Fig. 2A - palaeogeographical map of Europe for the Middle Jurassic (after Ziegler, 1990, modified); B - Polish Basin during the Middle Bathonian (bremeri zone, after Feldman-Olszewska, 1998, modified) and the location of the area studied

AM - Armorican Massif, BM - Bohemian Massif, CEBS - Central European Basin System, IBM - Iberian Meseta, IM - Irish Massif, LBM - London-Brabant Massif, MC - Massif Central High, MCA - Meta-Carpathian Arc, RHB - Rockall-Hatton Bank, UH - Ukrainian High

Ogrodzieniec. The deposits investigated are exposed in two active clay-pits near Zawiercie, in Blanowice and Ogrodzieniec (Fig. 1), situated in the southeastern tip of the outcrop belt. They have been documented as regards their stratigraphy, palaeontology, geochemistry and palaeoecology (e.g., Różycki, 1953; Pazdrowa, 1967; Szczepanik et al., 2005; Marynowski et al., 2007; Salamon and Zatoń, 2007; Szczepanik and Sawłowicz, 2008; Zatoń and Taylor, 2009; Zatoń, 2011; Zatoń et al., 2011, 2012; Barski, 2012). The Blanowice section exposes $\sim 12 \mathrm{~m}$ of dark grey and black, laminated mudstones with several horizons of, and loosely scattered, siderite and calcareous concretions (Fig. 3), representing the Middle Bathonian interval (subcontractus-morrisi zones) of the ore-bearing clays (Zaton et al., 2012). The Ogrodzieniec section consists of $\sim 14 \mathrm{~m}$ thick, laminated, dark grey and black mudstones (Fig. 3), assigned to the Middle and Upper Bathonian (bremeri-retrocostatum zones; Salamon and Zatoń, 2007; Zatoń et al., 2011). In the lowermost part of the section continuous levels of small siderite nodules occur, one of which comprises hiatus concretions described by Zatoń et al. (2006, 2011).

\section{METHODS}

In Ogrodzieniec and Blanowice clay-pits the deposits were carefully examined centimetre by centimetre, the lithology, sedimentary structures, bioturbation and benthic fauna being recorded. Intensity of bioturbation was estimated as ichnofabric index (I.I.), using the scheme of Droser and Bottjer (1986). To study the microfabrics, eight samples, showing various types of lamination and different intensities of bioturbation, were se- lected for thin section examination. They were stabilized in polyester resin using the method described by Jarosińska (2000) and 15 thin sections were prepared from them. Microscopic examination focused on the geometry of coarser grained accumulations (lenses/laminae), their arrangement (individual laminae/lamina sets) and their internal structure. The latter include micro-lamination (parallel/cross), arrangement of particles (graded/structureless) and character of lamina boundaries (sharp/diffuse/gradational). Sedimentary structures were documented on photographs made both in the field and under the microscope.

\section{RESULTS AND INTERPRETATION}

SEDIMENTARY STRUCTURES

The most common sedimentary feature, observed in studied mudstones of the Ore-Bearing Częstochowa Clay Formation, is variously developed parallel lamination (Fig. 4). This includes easy discernible flat accumulations of pale grey silt, very fine sand and shell debris (Fig. 5) and discrete laminae of background deposit, distinguished as colour banding.

\section{COLOUR BANDING}

Observations. This consists of parallel, laterally continuous bands, 2-25 $\mathrm{mm}$ thick, showing in exposures as subtle vertical variations in colour, from dark to light grey (Fig. 4A). Dark grey bands appear usually structureless, whereas lighter grey ones often show fine parallel lamination arranged in bundles 


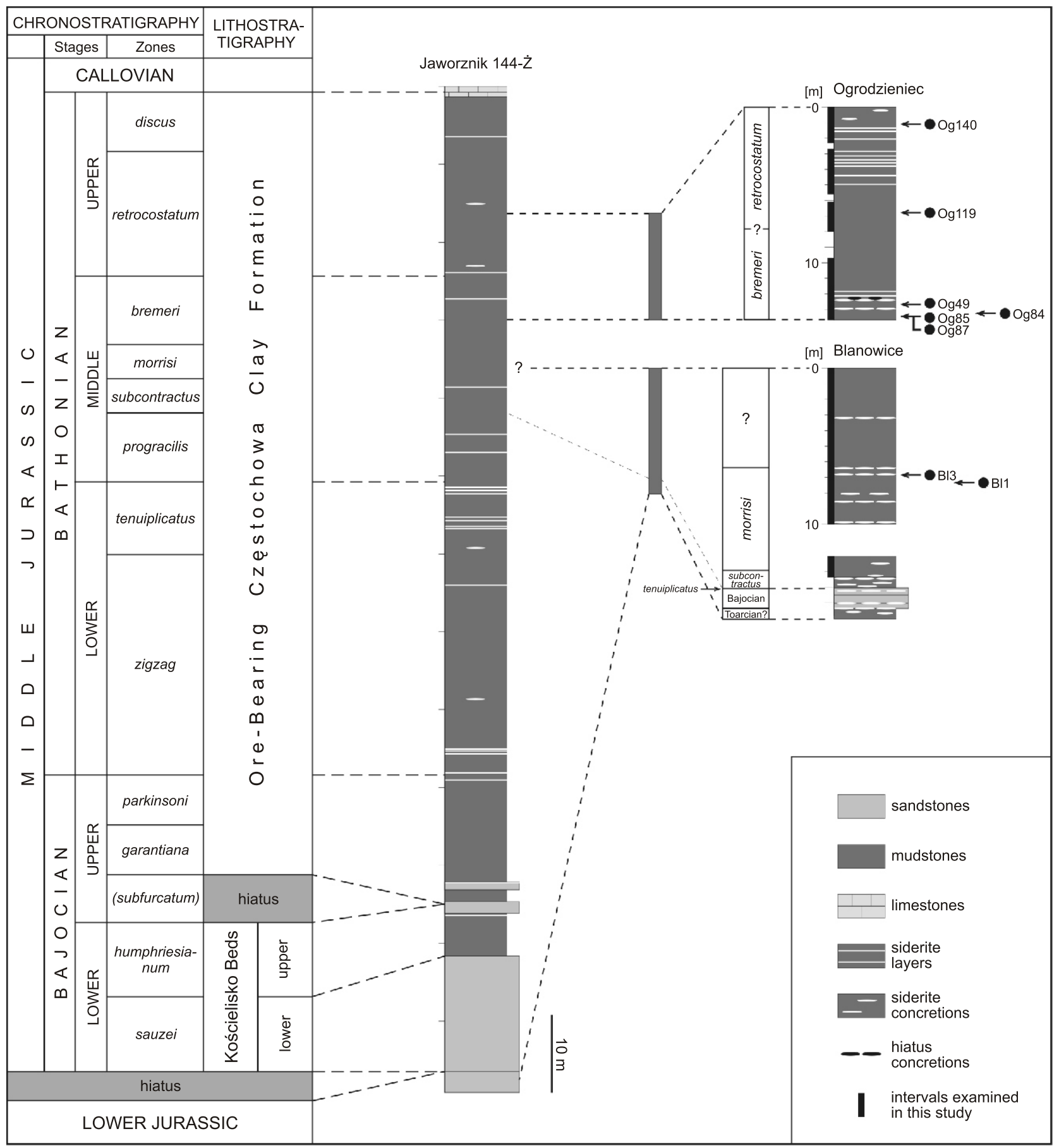

Fig. 3. Stratigraphy of Middle Jurassic deposits from the Silesian-Cracow region (after Kopik, 1998; Matyja and Wierzbowski, 2000, 2006; Barski et al., 2004) with a lithological log of the Jaworznik 144-Ż borehole (stratigraphy after Kopik, 1998)

Sections studied are shown to the right in greater detail with the location of samples selected for thin section analysis; biostratigraphical interpretation after Salamon and Zatoń (2007), Zatoń (2007) and Zatoń et al. (2011,2012) 

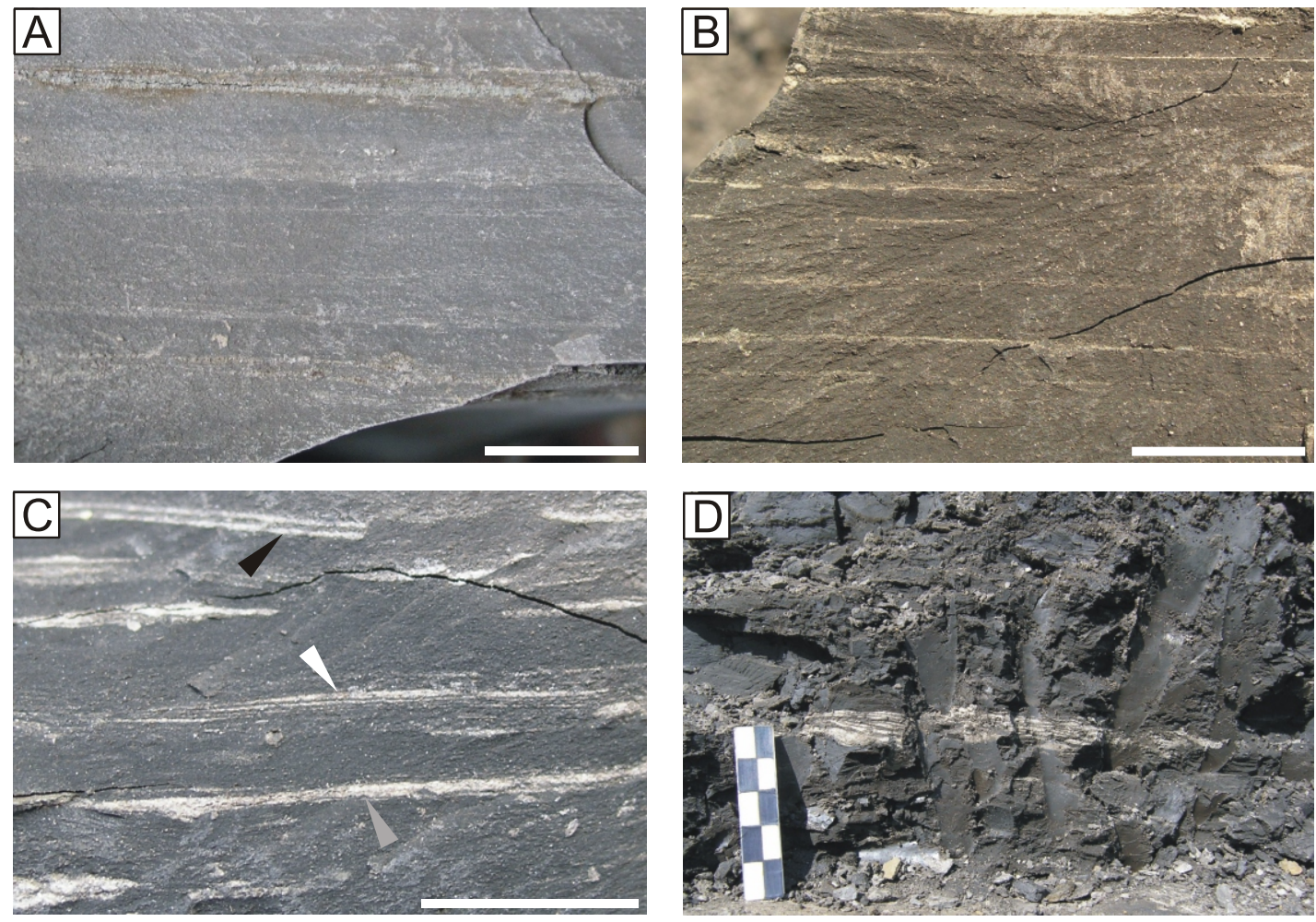

Fig. 4. Sedimentary structures from laminated mudstones of ore-bearing clays

A - colour banding consisting of parallel bands subtly differing in colour, light grey layer in the upper part of the picture is a fragment of a pyritized sand lens; $\mathbf{B}$ - thin parallel lamination; C - thick parallel laminae and laminae bundles: single lamina (grey arrow), pair of laminae (black arrow) and a bundle of five laminae (white arrow); D - elongated lens of very fine sand with low-angle and parallel lamination; Ogrodzieniec clay-pit, views perpendicular to bedding; scale bar in A-C is $1 \mathrm{~cm}$, scale bar in $D$ is in centimetres
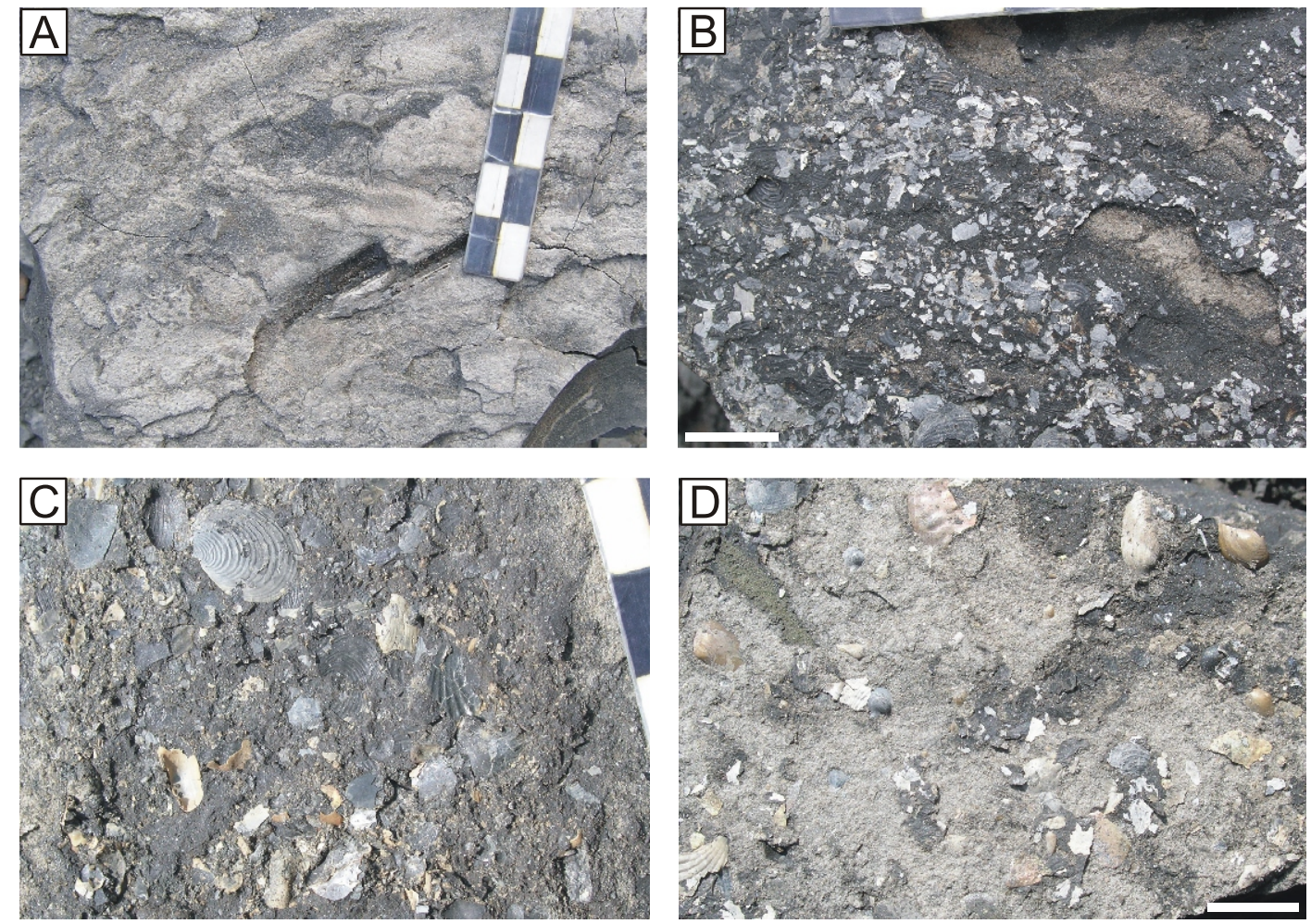

Fig. 5. Composition of silt, sand and shell debris accumulations

A - accumulation of very fine sand and silt (thick parallel lamina); B - accumulation of fragmented shells of the bivalve Bositra (thin parallel lamina); $\mathbf{C}$ - accumulation of silt and fragmented shells of different bivalves, one complete valve of Bositra is visible in the upper part of the picture (thin parallel lamina); D - accumulation of very fine sand and silt with coarse fragments of various bivalve and ammonite shells (thick parallel lamina), preserved single valves of small bivalves are in convex-up position; Ogrodzieniec clay-pit, parting plane views; scale bar in $A, C$ is in centimetres, scale bar in $B, D$ is $1 \mathrm{~cm}$ 

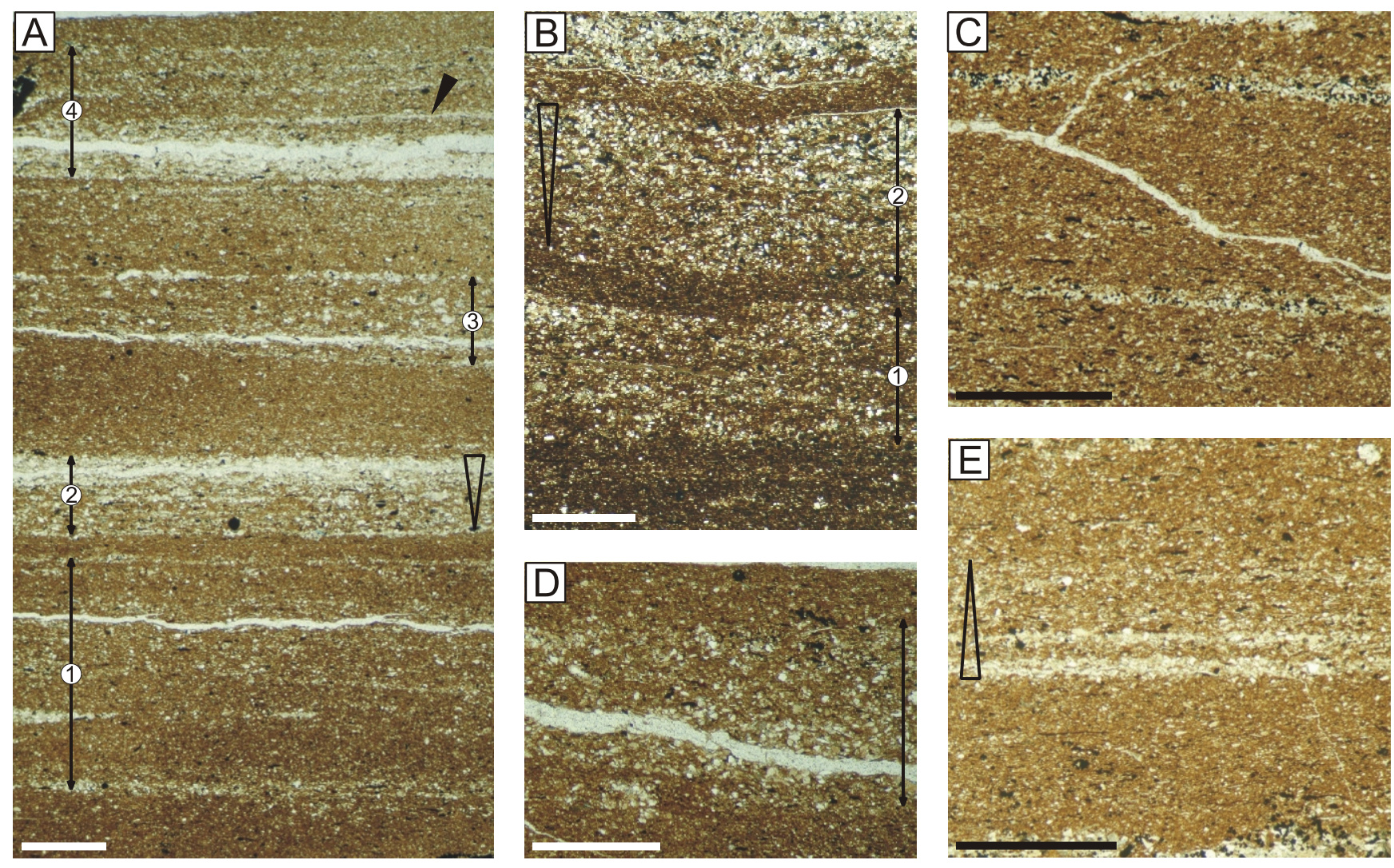

Fig. 6. Colour banding in thin section

A - intercalation of clayey and silt-rich bands; four silt-rich bands are visible: bands 1, 2 and 3 have distinct upper and lower contacts (partly blended by meiofauna burrowing) and different internal structure - band 1 is faintly laminated, band 2 is inversely graded, band 3 appears structureless; band 4 has a distinct bottom contact and gradational top and shows internal laminae gently inclined to the left (one is indicated by an arrow); B - two silt-rich bands with distinct top and gradational bottom contacts; band 1 appears structureless, band 2 is inversely graded; $\mathbf{C}$ - two thin quartz laminae with indistinct boundaries within clay; $\mathbf{D}$ - silt-rich band with diffuse upper and lower contacts; $\mathbf{E}$ - thin silt-rich band developed as graded rhythmite, showing upward decrease in the thickness of laminae; A, C-E - Ogrodzieniec clay-pit (A sample Og84, C, E - sample Og87, D - sample Og49); B - Blanowice clay-pit (sample Bl1); scale bar is $1 \mathrm{~mm}$

5-25 mm thick. The number of laminae in particular bundles usually does not exceed five.

Microscopic examination reveals that colour variations reflect grain size distribution: dark grey bands are composed of clay with a subordinate admixture of quartz, whereas lighter grey bands are rich in quartz silt with a small admixture of very fine sand (Fig. 6A, B). Fine mica flakes and elongated organic particles, occurring in the clayey parts, are often parallel orientated, however, a random fabric resulting from bioturbation was also observed. Rarely, very thin quartz laminae with diffuse boundaries occur within clayey bands (Fig. 6C). They are represented by individual laminae or arranged in bundles. The nature of silt-rich bands is variable. They may have diffuse top and bottom contacts (Fig. 6D), sharp top and bottom contacts (Fig. 6A), sharp lower contacts and gradational tops (Fig. 6A) or sharp tops and gradational bottoms (Fig. 6B). Silt-rich bands with diffuse boundaries appear structureless (Fig. 6D) or, less commonly, are indistinctly laminated. Those with sharp lower contacts and gradational tops are structureless or normally graded. Usually, this is a not true size grading, but represents the transition from silt-rich to less silt-rich sediment. Locally, faint parallel lamination can be observed, with laminae inclined at a low angle (Fig. 6A) or forming graded rhythmite units (Fig. 6E). Laminae with sharp tops and gradational bottom contacts are rare. They can appear structureless or inversely graded
(Fig. 6B). The internal structure of silt-rich bands with both sharp top and bottom contacts is the most diverse. They may be structureless, finely laminated or inversely graded, showing enrichment of the uppermost part in silt (Fig. 6A).

The colour banding represents a basic type of stratification. Although it is barely visible, due to its subtle appearance and susceptibility to destruction by bioturbation, it is the most common component of successions and provides the context for other lamination types.

Interpretation. Colour banding marks periodical changes of sedimentation from clay-dominated to silt-rich. Clayey zones mark deposition of the finest particles from suspension, consistent with the parallel alignment of mica flakes and organic particles observed in some of them. Such sedimentation alternated with periods of increased input of silt and subordinate sand. Silt-rich bands with diffuse top and bottom contacts indicate gradual change in silt supply and may have been deposited from detached turbid layers or suspension clouds (cf. Schieber, 1990, 1994). Even lamination within these bands represents repeated variations in suspension composition. Similarly, even silt laminae occurring in clayey zones represent deposition from thin suspension clouds.

Laminae with sharp lower contacts and gradational tops, often normally graded, as well as graded rhythmites, are the result of short-lived sedimentation events related to fine-grained 
suspension currents flowing near the bottom (Stow and Shanmugam, 1980; O'Brien, 1996). Silt-rich bands with sharp both top and bottom contacts and inverse grading probably formed by current reworking of the upper part of structureless or normally graded bands with sharp lower boundaries (Schieber, 1994; Hiscott, 2003). Rhythmic fine lamination, observed in silt-rich bands, may be interpreted as a result of different processes including depositional sorting by boundary-layer shearing (Stow and Bowen, 1980), bedload sorting of particles by their weight, density and shape due to irregularities in the flow (Kuenen, 1966; Piper, 1972) or simultaneous bedload transport of coarse silt and flocculated fine materials during migration of bedforms (McBride et al., 1975; Schieber et al., 2007; Schieber and Yawar, 2009). Migration of small ripples is inferred from gently inclined silty laminae, observed in some silt-rich bands (Fig. 6A band 4). Inversely graded laminae, showing true grain size gradation, mark probably increase of current velocity during the depositional event. Sharp tops point to current reworking of bottom sediment in the final stage of deposition, whereas gradational lower contacts suggest a soft or soupy character of the bottom, on which silt was deposited (Schieber, 1994).

THIN PARALLEL LAMINAE

Observations. These are thin, $0.1-0.3 \mathrm{~mm}$ thick, parallel, discontinuous accumulations of very fine sand, silt and shell debris (Fig. 4B). They may be composed of (1) only sand and silt, (2) sand, silt and fragmented shells of various bivalves and ammonites as well as rare single valves of small bivalves, (3) only fragmented shells. The latter usually consist of fragments and a few whole valves of Bositra (Fig. 5B). Most individual valves observed in thin parallel laminae are in convex-up position.

Thin section examination reveals the nature of the silt-sand laminae. Beside quartz grains, which are the main component, they contain also subordinate mica flakes, organic particles and concentrations of diagenetic pyrite (Fig. 7A). They vary in thickness and wedge out laterally, representing in fact long and flat lenses (Fig. 7A, B). They have sharp, often irregular both upper and lower contacts (Fig. 7A) or, rarely, sharp bottom contacts and slightly gradational tops (Fig. 7B). In both cases laminae have structureless appearance.

Thin parallel laminae usually occur in silt-rich bands of colour banding, at various positions: at the base, in the middle or in the top. Locally they occur directly within the clayey zones.

Interpretation. The lenticular shape, sharp lower and upper boundaries and irregular, probably erosive character of the bottom contacts suggest bedload transport and indicate that most of the thin parallel laminae were deposited by bottom currents (e.g., Schieber, 1990, 1999). They represent very thin, initial starved ripples moving across a cohesive muddy bottom. Reworking by currents is supported by the convex-up orientation of bivalve valves, observed in some shell debris accumulations (Futterer, 1978; Brett and Allison, 1998). Laminae with sharp bottom contacts and gradational tops were probably deposited by currents carrying fine-grained suspended sediment near the bottom (Stow and Shanmugam, 1980; O'Brien, 1996). The occurrence of thin parallel laminae within the silt-rich bands indicates that they formed during the same depositional events as these bands. Bottom-flowing currents, carrying suspended material from which silt-rich bands were deposited, were also responsible for winnowing of fine particles and reworking of coarse silt and sand to form flat starved ripples.
THICK PARALLEL LAMINAE AND LAMINAE BUNDLES

Observations: These are parallel, discontinuous laminae, up to $0.7 \mathrm{~mm}$ thick, often arranged in bundles comprising up to five laminae (Fig. 4C). Bundles observed in small samples often reveal the thickness of laminae decreasing downwards or their thinning both upwards and downwards, giving the impression of inversely graded or symmetrical units (white arrow on Fig. 4C). However, examination over longer distances reveals that these bundles are stacks of elongated, flat lenses that probably resulted from aggradation of successive generations of migrating starved ripples. Visible changes of thickness may reflect either variations of ripple size or cross-section orientation with respect to the elongation of particular lenses.

Laminae consist of very fine sand and silt, locally with admixture of fragmented shells of various bivalves and ammonites as well as preserved single valves of small bivalves, which are mainly in convex-up position (Fig. 5D). Beside quartz, laminae contain rare micas, diagenetic pyrite grains and organic matter, visible in thin section (Fig. 7C, D). The internal structure of the quartz laminae is variable. They have usually sharp upper and lower contacts and a structureless appearance (Fig. 7C). However, there are also examples with sharp tops and diffuse bottoms (Fig. 7E) or with both boundaries diffuse (Fig. 7D). Rarely, normal grading can be observed (Fig. 7D). Pairs of laminae consist usually of a thicker lower lamina, which locally has gradational upper contact, and a thinner upper lamina with distinct upper and lower contacts (Fig. 7F). These are separated by a zone impoverished in quartz grains.

Thick parallel laminae occur usually in silt-rich bands of colour banding and occupy, as the thin laminae, various positions. Rarely, they appear directly in clayey zones. Bundles of laminae themselves form silt-rich bands.

Interpretation. The origin of thick parallel laminae and laminae bundles is similar to that of thin parallel laminae and is linked with the activity of bottom-flowing currents. The more abundant sediment supply and more intensive reworking here resulted in the greater thicknesses of laminae. These currents, which brought in suspended sediment, reworked it recurrently leading to the formation of stacks of discontinuous sand and silt accumulations (lamina bundles), which represent initial starved ripples. The current-related origin of them is consistent with their sharp boundaries, lenticular shape and the convex-up position of preserved bivalve valves (Futterer, 1978; Schieber, 1990, 1999; Brett and Allison, 1998). Diffuse lower contacts of some laminae suggest periodically soft or soupy character of the bottom (Schieber, 1994). Deposition of normally graded laminae and laminae with diffuse tops may be related directly to suspended sediment flows. Pairs of laminae are probably the result of current reworking of tops of thick, normally graded bands.

\section{LENSES}

Observations. Lenses are composed of very fine sand and silt, locally with some admixture of shell debris, and they are up to $12 \mathrm{~mm}$ thick (Fig. 4D). They always have sharp upper and lower contacts and are often loaded. Internally, they are structureless (Fig. 8A), cross-laminated (Fig. 8B, D, E) or parallel- and low-angle laminated (Fig. 8A, C, F). Internal micro-lamination consists of interlayered sand/silt and thin clay laminae, the latter composed of clay floccules. In thin section the internal structure can be more complex. In a few cases cross-lamination 



\section{Fig. 7. Parallel laminae in thin section}

A, B - thin parallel laminae: A - two thin quartz laminae (arrowed) within laminated background deposit; the lower lamina occurs in the top of a normally graded silt-rich band (band 1) and wedges out to the right; the upper one is enriched in diagenetic pyrite grains (black dots) and occurs within a laminated silt-rich band (band 2); B - thin quartz lamina (arrow) with sharp irregular bottom contact and gradational top; it occurs in a clayey band bordered by two laminae with diffuse boundaries, representing laminated background deposit; $\mathbf{C}-\mathbf{F}$ - thick parallel laminae and bundles: C - two quartz laminae with sharp lower and upper boundaries; the upper one contains an admixture of diagenetic pyrite grains (black dots); D - two laminae from the bundle; the lower one has sharp lower and upper contacts and serves as the basal lamina of a graded rhythmite unit; the upper one is normally graded and has diffuse boundaries, resulting most probably from bioturbation; black spots are organic particles; $\mathbf{E}$ - single lamina with diffuse lower and sharp upper contact; small burrows are visible in the top (some indicated by arrows); $\mathbf{F}$ - pair of quartz laminae separated by a quartz-impoverished zone; the lower lamina is thicker and is normally graded, the upper lamina is thinner and has sharp boundaries; A-C, E, F - Ogrodzieniec clay-pit (A - sample Og84, B - sample Og85, C - sample Og49, E, F - sample Og87); D - Blanowice clay-pit (sample BI3); scale bar is $1 \mathrm{~mm}$ 

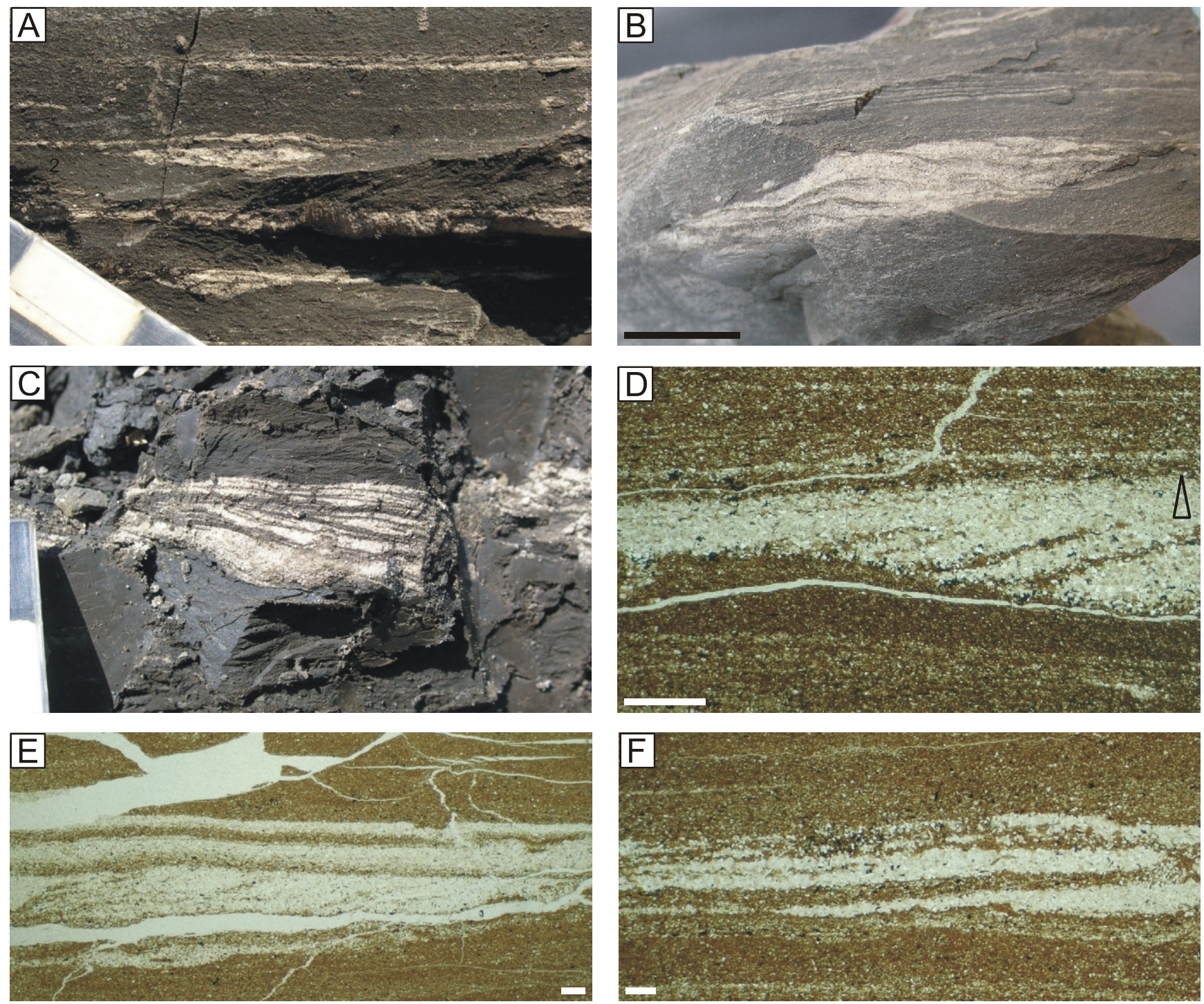

Fig. 8. Sand-silt lenses

A - small, partly loaded lenses of very fine sand; the lower one has indistinct low-angle lamination, the upper one appears structureless; B cross-laminated lens of very fine sand; $\mathbf{C}$ - sand lens with low-angle and parallel lamination; $\mathbf{D}-\mathbf{F}$ - lenses in thin section: $\mathbf{D}-$ cross-laminated lens, in which micro-lamination is confined to the lower part and the upper part is indistinctly graded; $\mathbf{E}$ - graded rhythmite unit with cross-laminated lens at the base; F - low-angle lamination visible due to the presence of distinct clay microlaminae; Ogrodzieniec clay-pit (D-F - sample Og85); A, C - scale bar is in centimetres, B - scale bar is $1 \mathrm{~cm}$, D-F - scale bar is $1 \mathrm{~mm}$

is confined to the lower part of the lens, whereas the upper part is structureless or normally graded (Fig. 8D). Thicker sand lenses often occur at the bases of graded rhythmites (Fig. 8E).

Sand and silt lenses most commonly occur in silt-rich bands of colour banding. Rarely, they appear within clayey zones. Thin lenses, as do the thin and thick laminae, may occupy various positions within silt-rich bands, whereas thick lenses occur usually at their base. They often occur at the bottoms of graded rhythmites or begin graded sequences, passing upwards into structureless or finely laminated silty clay and structureless clay.

Interpretation. The origin of silt-sand lenses may be linked with a relatively abundant supply of sediment that was transported by traction currents. The current origin of lenses is confirmed by their lenticular shape, sharp boundaries and internal structure, including cross-, parallel- and low-angle lamination (e.g., Schieber, 1994, 1999; O’Brien, 1996; Schieber and
Yawar, 2009). The alternation of clay and quartz laminae suggests simultaneous transport of silt, sand and flocculated clay, which formed piles moving over the bed and built up laminae of different composition. Transport, as in the case of the thin and thick parallel laminae, was by bottom-flowing currents carrying suspended sediment. Such interpretation is supported by the occurrence of sand lenses in the bottoms of graded rhythmites, the presence of graded sequences: sand lens - structureless or laminated silty clay - structureless clay, as well as by the complex structure of some lenses, in which cross-lamination is overlain by normally graded sediment. Each sequence records a single depositional event, during which bedload transport was followed by deposition from suspension. Such structures are known from many ancient and modern deposits of fine-grained suspension currents (e.g., Stow and Shanmugam, 1980; Schieber and Yawar, 2009). 

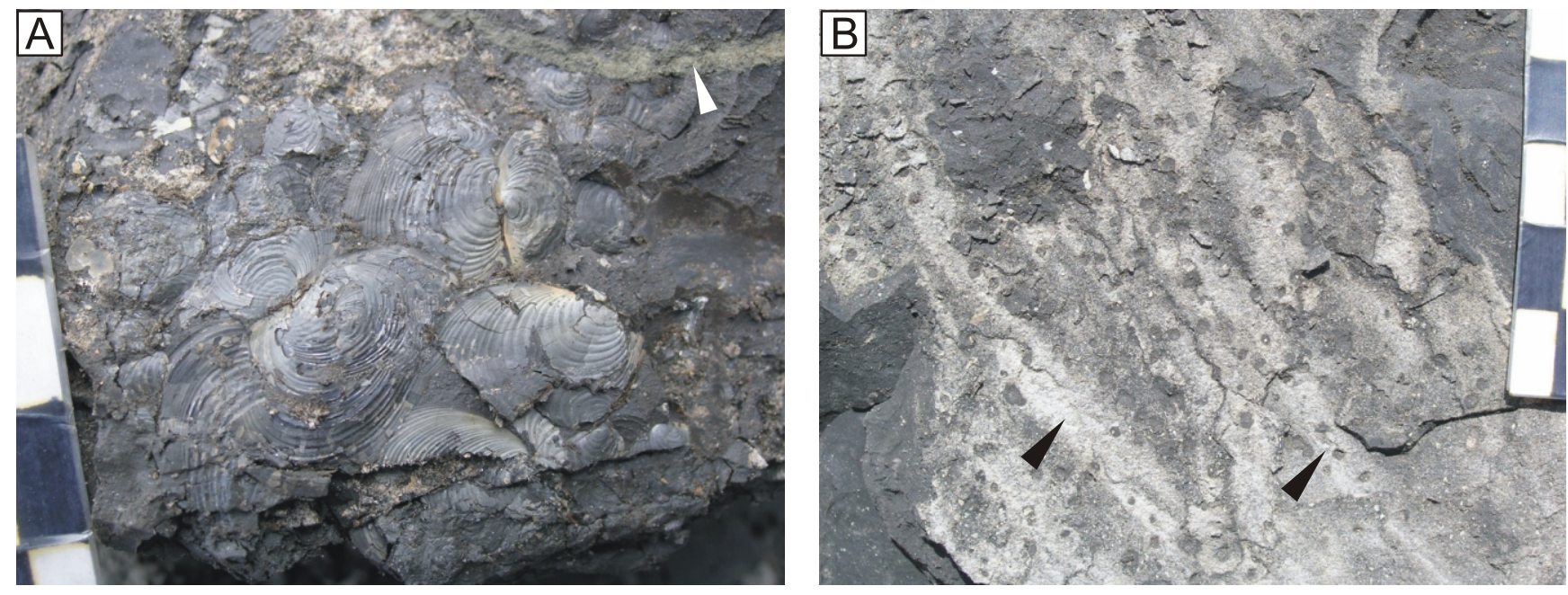

Fig. 9. Benthic fauna and trace fossils

A - part of bedding-plane accumulation of the bivalve Bositra; articulated shells are in "butterfly position"; in the upper right corner of the picture a pyritized burrow is visible (arrowed); B - sand/silt accumulation cut by Chondrites (dark dots); linear features indicated by arrows represent probable ripple crests; Ogrodzieniec clay-pit, parting plane views; scale bar is in centimetres

\section{BENTHIC FAUNA AND BIOTURBATION}

The benthic fauna in the mudstones studied is rare and of low diversity. The only common body fossils occurring as individual specimens and in bedding-plane accumulations are bivalves Bositra (Fig. 9A). Many of their shells are articulated and preserved in "butterfly position". Other benthic organisms, found directly in mudstones, occur rarely and include small bivalves belonging to the families Nuculidae (Palaeonucula) and Nuculanidae (Nuculana, Mesosaccella) as well as small gastropods. These bivalves are normally preserved as separate valves or smaller fragments. Scarce specimens with both valves are hardly ever in life position. Other bivalves were observed only in shell debris accumulations, preserved as separate valves and shell fragments. They represent five families: Astartidae (Trautscholdia), Inoceramidae (Parainoceramus), Entoliidae (Entolium), Pectinidae (Camptonectes) and Oxytomidae (Oxytoma), accompanied by nuculids and nuculanids.

Trace fossils recognized in exposures are scarce and include mainly deep burrowing ichnogenera: Chondrites (Fig. 9B), Trichichnus and undetermined pyritized burrows (Fig. 9A). Trichichnus and pyritized burrows are scattered through the entire section, whereas Chondrites is visible mainly in sand and silt accumulations. The occurrence of other ichnofossils including Palaeophycus and occasional Protovirgularia is linked, as with Chondrites, to sand and silt accumulations. As burrows with pyritized fill are easier discernible in exposure, such uneven distribution of trace fossils might reflect preservational bias. However, in other exposures of ore-bearing clays Chondrites, Palaeophycus and other non-pyritized ichnofossils are visible regardless of the lithology (Gedl et al., 2006a, b, c; Leonowicz, 2012). Moreover, thin sections rarely reveal macroburrows, suggesting that their scarcity is rather a matter of the organisms preference, not their preservation.

Macroscopically, bioturbation intensity is scarce $($ I.I. = 2) for background deposit and low (I.I. = 3) for accumulations of sand, silt and shell debris. Microscopically, however, the bioturbation is much more common and has a more diverse pattern. This results mostly from discrete, undetermined small burrows, discernible only in thin sections, which in places form dense population. They are represented by straight or slightly curved, flattened tunnels, oriented horizontally or obliquely to the stratification, less than $2 \mathrm{~mm}$ thick and up to $2 \mathrm{~cm}$ long (Fig. 10A, B, E). They are better visible in clay-silt bands thanks to their infill, which differs slightly from surrounding sediment in colour and/or grain size. In sand-silt zones they appear as a small-scale disturbance of internal micro-lamination within sand lenses and disruption of thin silt-sand laminae (Fig. 10D, E). The occurrence of macroscopically invisible bioturbational structures in laminated mudstones has already been reported from some black shale formations and interpreted as the work of worms "swimming" through soupy, soft sediment (Lobza and Schieber, 1999; Schieber, 2003). Considering the small scale and obscure nature of the burrows in deposits studied, they should be regarded as cryptobioturbation (Pemberton et al., 2008), referred also to as microbioturbation (Pratt, 1984; Sageman, 1989). Four grades of sediment disruption by them may be distinguished:

(I) No bioturbation (I.I. = 1). Such fabric was observed in clay-rich zones, where it was expressed by parallel orientation of mica flakes and undisturbed faint silt laminae (Fig. 10C), as well as in silt-rich zones where undisturbed lamination appeared (Fig. 10D, E). Non-bioturbated deposits form layers up to $1 \mathrm{~cm}$ thick within bioturbated sediments. At exposure, they are represented by distinctly laminated mudstones;

(II) Sparse bioturbation (I.I. = 2-3), which does not significantly disturb lamination. In this fabric small, discrete small burrows are concentrated within particular laminae, not disrupting their boundaries (Fig. 10E), although they can be quite abundant $(\mathrm{I} . \mathrm{I} .=3)$. Thin silt-sand laminae can be crosscut locally by occasional burrows (I.I. = 2), which however, do not obliterate lamination (Fig. 10D, E). Macroscopically, sparsely bioturbated deposits do not differ in appearance from non-bioturbated sediments;

(III) Low bioturbation (I.I. = 3). In this fabric boundaries of laminae are indistinct due to bioturbation, though clay-rich and 

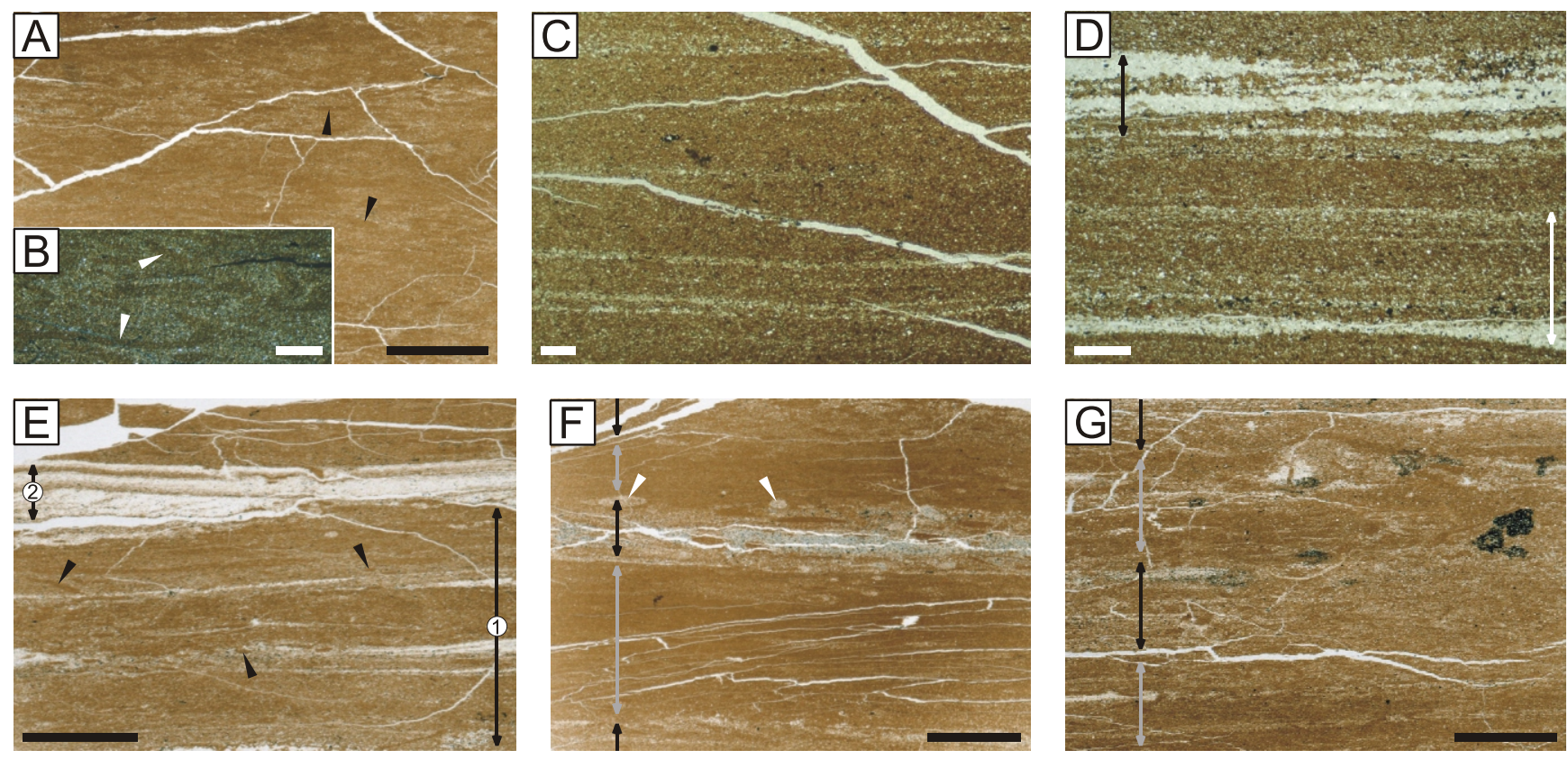

Fig. 10. Cryptobioturbation in thin section

A, B - sediment reworked by discrete microburrows (some of them indicated by arrows), A - plane polarized light, B - crossed polars; C, D no bioturbation (I.I. = 1): undisturbed thin silt laminae in clayey zone (C) and faint lamination in silt-rich band (D - white arrows); in the upper part of D low-angle lamination in the sand lens is slightly disturbed by sparse bioturbation (black arrows); $\mathbf{E}-$ sparse bioturbation (I.I. = 2-3) in clayey band 1 and no bioturbation in sand/silt band 2; discrete microburrows (some of them indicated by arrows) cut thin silt laminae but do not obliterate them; F - low bioturbation (I.I. = 3): boundaries of laminae are indistinct but clayey zones (grey arrows) and silt-rich bands (black arrows) are easily visible; flattened burrows filled with quartz silt (white arrows) probably represent Chondrites; $\mathbf{G}$ - moderate bioturbation (I.I. = 4): clayey zones (grey arrows) and silt-rich bands (black arrows) are poorly visible due to obliteration of their boundaries; Ogrodzieniec clay-pit (A - sample Og140, B, D, E - sample Og85, C - sample Og84, F - sample Og119, G - sample Og49); B-D - scale bar is $1 \mathrm{~mm}, \mathrm{~A}-\mathrm{G}$ - scale bar is $5 \mathrm{~mm}$

silt-rich zones are still clearly visible (Fig. 10F). Internal lamination within these zones is disturbed and may occur as parallel stripes. Macroscopically, low-bioturbated deposits are represented by easily discernible colour banding sometimes with indistinct sand-silt stripes;

(IV) Moderate bioturbation (I.I. = 4). In this fabric clay-rich and silt-rich bands are weakly visible, their boundaries are blurred and internally they have structureless appearance due to the disruption of silt-sand laminae (Fig. 10G). In places, indistinct parallel flasers of different colour occur. Macroscopically, moderately bioturbated deposits are represented by indistinct colour banding or structureless mudstones, locally with vague parallel orientated fabric.

If the lithology is homogeneous and lacks macroscopically visible silt-sand laminae, the only manifestation of the third and fourth grades of cryptobioturbation is dispersion of fine shell debris that, in sparsely bioturbated deposits, normally occurs as bedding-plane accumulations.

Due to the scarcity of macroburrows, determination of cross-cutting relationships and evaluation of tiering is difficult. Nevertheless, by comparison with observations from other exposures of ore-bearing clays, in which similar trace fossils occur (Gedl et al., 2006a, b, c; Leonowicz, 2012), ichnofossils from the sections studied may be assigned to at least four tiers. The shallowest tier consists of biodeformational structures represented by cryptobioturbation; the second tier contains Palaeophycus and probably Protovirgularia (although the relationships between these burrows have not been recognized); the third tier is occupied by Chondrites and the deepest one contains Trichichnus and pyritized burrows.

\section{DISCUSSION}

\section{SEDIMENTARY ENVIRONMENT}

Sedimentary structures in the mudstones studied indicate deposition in conditions that ranged from quiet suspension settling to intermittently current-influenced. The lack of wave-generated structures and distinct erosional scours suggest that the sea-floor was below the storm-wave base and beyond the reach of channelized bottom flows. Mud deposition here can be ascribed to three major processes: (1) settling of particles from the suspension through the water column, (2) deposition from near-bottom flows of suspended sediment, and (3) reworking and transport of sediment by tractional currents. The rarity of structures resulting from quiet settling from suspension indicates that processes of the first category were subordinate. They constituted the background for other sedimentation types but are recorded only by some intervals of colour banding. The fine-grained sediment forming them settled from suspended sediment plumes, spreading out from river mouths as hypopycnal flows. Increased silt supply, leading to the formation of silt-rich bands with diffuse boundaries and even silt laminae, resulted from increased discharge from river floods. The other source of silt might be resuspension of sediment in shallow areas during storms and its offshore transport in the form of suspension clouds.

Most of the sedimentary structures, observed in the mudstones studied, reflect depositional events linked with bottom currents carrying fine-grained suspended sediment. Deposition 
can be interpreted as an interplay of two processes: (1) settling from the suspended sediment flows moving near the bottom with simultaneous transport of the lower portion as bedload and (2) intermittent reworking of bottom sediment by bottom flows with redeposition of the coarsest material in form of flat starved ripples. Such structures as laminae with sharp lower and gradational upper contacts, normal grading, fine parallel lamination and graded rhythmites indicate settling from fine-grained suspension flows (e.g., Reineck and Singh, 1972; Stow and Shanmugam, 1980; Brett, 1983; Schieber, 1994, 1999). Inversely graded laminae that show transition from silt-poor to silt-rich mud and discontinuous silt-sand laminae with sharp boundaries suggest current reworking of the upper part of the bottom sediment (Schieber, 1994), whereas lenticular silt-sand laminae with cross- and low-angle lamination and some kinds of fine sub-parallel lamination in mudstones point to bedload transport of silt, sand and clay floccules (e.g., Stow and Shanmugam, 1980; Schieber et al., 2007; Schieber and Yawar, 2009).

The sequences of structures mentioned above are known from many modern and ancient deposits, representing both fine-grained turbidites (Stow and Shanmugam, 1980; Hill, 1984; Stow and Piper, 1984; Schieber, 1994, 1999) and distal tempestites (Reineck and Singh, 1972; Brett, 1983; Aigner, 1985; Pedersen, 1985; Wignall, 1989; Myrow, 1992; Schieber, 1994; Schieber and Yawar, 2009). Deposits of these two origins are often difficult to distinguish. Taking into account that Polish Basin was a shallow epicontinental sea in the Middle Jurassic and that the locality studied was situated in a marginal part of it, a storm origin of the event layers described is more likely and is consistent with several characteristic features within them. Although part of the material forming the event deposits was brought in from shallower areas of the basin, the range of this redistribution seems to be limited. Silt-sand event laminae do not significantly differ in petrographic composition from the background sediment, whereas turbidites often differ distinctly from the host rock (Einsele and Seilacher, 1991). The shell debris accumulations described consist of fragmented shells of shallow-water benthic fauna, whereas turbidites typically comprise mixed associations of shallow and deep water species (Einsele and Seilacher, 1991). The evidence for import of silt and sand from other parts of basin rather than redeposition in situ is the difference in quartz grain size, which is usually coarser in the event laminae than in intervening background sediment. Also shell debris had to be brought in from other parts of basin, as most of bivalves found in the event laminae do not occur in the adjacent mudstones. The only exception is debris of the bivalve Bositra, which is a common constituent of the autochthonous benthic association. Their in situ occurrence is confirmed by the frequent preservation of articulated specimens in "butterfly position" typical of not displaced fauna. The co-occurrence of shell debris and well-preserved articulated specimens in neighbouring laminae suggests that the former is nearly autochthonous, being resuspended and settled without significant transport. This feature, in turn, is also characteristic of storm deposits.

Field observations from several modern shelf environments show that the redistribution of mud from the inner shelf by storm-generated offshore flows is an important source of sediment accumulating in the mid-shelf zone (Wright and Friedrichs, 2006). A significant role in this redistribution is played by across-shelf transport by wave-induced, gravity-driven density flows, carrying suspended sediment in the form of fluid mud layers (e.g., Sternberg et al., 1996; Traykovski et al., 2000; Fain et al., 2007). These flows, called wave-induced turbidity currents (Traykovski et al., 2000), resemble in some aspects turbidity currents that form on continental slopes; however, they differ from the latter in that they are supported by wave and current-induced boundary shear stresses and do not require autosuspension for sustenance. As a result, they can form even on gently sloping shelves. Such an origin may be inferred for many ancient fine-grained storm deposits, for example those referred in the literature to as muddy tempestites (Aigner, 1985) or mudrocks associated with obrution beds (= smothered bottom - e.g., Brett, 1983; Parsons et al., 1988). Parsons et al. (1988) proposed a sedimentation model, in which most of the shale layers in outer-shelf settings resulted from blanketing by mud that came in as storm-induced, thick slurries flowing near the bottom. A similar origin of obrution horizons, including transport of suspended mud by gravity-driven turbid flows, was inferred by O'Brien et al. (1994). Sedimentary structures observed in X-radiographs of modern sediments deposited by wave-induced turbidity currents include sequences of interlaminated sand, silt and mud, commonly revealing laminae that downlap onto a basal surface and are overlain by structureless mud (Schieber and Yawar, 2009). Based on these observations Schieber and Yawar (2009) suggested that fluid mud deposits consist of a lower portion transported as bedload and an upper one that settled from a mud-rich suspension. A similar mechanism is postulated also for the ore-bearing clays studied and it is likely that wave-induced turbidity currents might have played significant role in their deposition.

The thickness and type of event laminae described reflect the intensity of storms, which governed volume of sediment input and, indirectly, distance of depositional site from the shoreline (Fig. 11). The weakest storms did not supply any material from shallower zones but reworked sediment nearly in situ leading to formation of thin accumulations of Bositra shell debris and some inversely graded silt-rich bands, resulting from winnowing of fine particles from the upper part of earlier accumulated sediment. The strongest storms brought significant amounts of quartz sand and led to the formation of sequences comprising relatively thick sand lenses. Considering the vicinity of the land it is most likely that the source of material forming the event deposits was shallow-water sediment accumulating in the nearshore zone. However, it cannot be excluded that - even in such a marginal part of the basin - the sea-floor took the form of swells and depressions, the former serving as a supplementary source area for muddy suspended sediment and shell debris. Synsedimentary tectonic activity, which might result in morphological differentiation of the depositional area, is suggested by the occurrence of neptunian dykes, reported from exposures of the ore-bearing clays (Barski, 2012). These likely did not form until the Kimmeridgian (Barski, 2012), though it is possible that vertical tectonic movements started even earlier.

\section{PRESERVATION OF SEDIMENTARY STRUCTURES}

Thin section examination shows that benthic meiofauna burrowed just as frequently within clayey and silt-rich zones, whereas in thick sand-silt laminae and lenses cryptobioturbation is sparse or absent. The latter deposit may be reworked by larger animals, producing trace fossils such as Palaeophycus and Chondrites, which however, are not abundant in the sections studied. As a result, thick laminae and lenses may be preserved and still discernible even in successions with dense networks of microburrows, which can be easy overlooked during macroscopic examination. The limited extent of material redistribution by meiofauna has led also to preservation of colour banding in deposits with bioturbation reaching even $60 \%$ $(\mathrm{I} . \mathrm{I} .=4)$, although bands here display disrupted internal struc- 


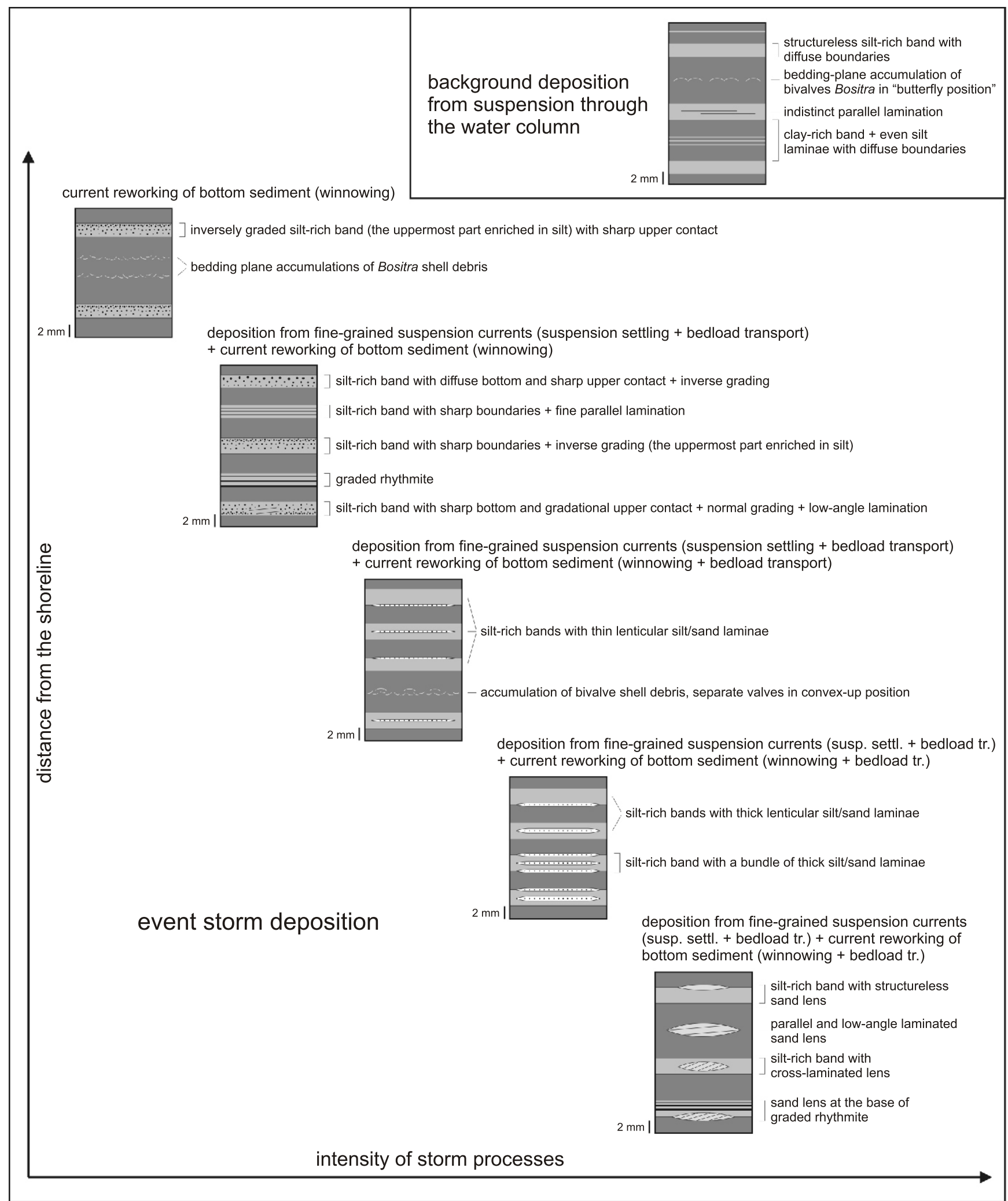

Fig. 11. Summary of deposit features in the Ore-Bearing Częstochowa Clay Formation that are related to the intensity of depositional processes and the distance from the shoreline 
ture and blurred boundaries. Complete disruption of colour banding requires the activity of larger animals, which would mix sediment between adjacent layers. Similar observation has been made in modern deposits, in which micro- and meiofaunal bioturbation caused broadening and disruption of primary lamination but was not sufficient to obliterate it (Behl, 1995).

\section{BOTTOM OXYGENATION}

Preservation of primary lamination in dark, organic-rich mudstones is usually interpreted as an indication of low oxygen levels at the depositional interface that prevents bioturbation (Wignall, 1994). The common presence of biogenic structures in the deposits studied is not consistent with truly anoxic conditions on the seafloor. However, the impoverished associations of trace fossils and benthic fauna point to some oxygen deficiency, an indication reinforced by the dominance of ichnofossils typical of oxygen-poor settings, such as Chondrites and Trichichnus (Bromley and Ekdale, 1984; McBride and Picard, 1991) and shelly endofauna represented by nuculoid bivalves, known for their high tolerance of low oxygen levels (Sageman et al., 1991). A monospecific epibenthic assemblage consisting of the bivalve Bositra, typical of low-oxygen environments (Sageman et al., 1991; Savrda and Bottjer, 1991; Bottjer and Savrda, 1993), suggests also that bottom waters were depleted in oxygen.

The uneven distribution and variable intensity of bioturbation imply that conditions on the sea-floor changed with time. The basic component of the ichnofabric is cryptobioturbation, which is the most common biogenic structure in the deposits studied and serves as a background for other trace fossils. This resulted from the activity of a shallow burrowing meiofauna that could live in extremely poor-oxygenated conditions, even on an anoxic sea-floor $\left(<0.1 \mathrm{ml} / / \mathrm{O}_{2}\right.$, Savrda et al., 1984; Bottjer and Savrda, 1993; Behl, 1995). Trichichnus and pyritized burrows are much less common, but also occur throughout the section. They represent the deepest tier of the ichnofabric and are interpreted as chemosymbiotic organisms, preferring oxygen-poor conditions (McBride and Picard, 1991; cf. Leonowicz, 2012). Representatives of shallower tiers - Chondrites, Palaeophycus and Protovirgularia - occur mainly within sand and silt accumulations, recording storm event sedimentation. Palaeophycus, interpreted as an open dwelling burrow of a polychaete (Pemberton and Frey, 1982; Pemberton et al., 2001), and Protovirgularia, representing the crawling traces of bivalves (Seilacher and Seilacher, 1994), require well-oxygenated conditions, whereas deep-feeding Chondrites tolerates low oxygen levels, burrowing shallowly in an oxygen-limited substrate and to deeper levels under well-oxygenated bottom water conditions (Bromley and Ekdale, 1984; McBride and Picard, 1991). Such a distribution of trace fossils displays trends consistent with the oxygen-related trace fossil model of Savrda and Bottjer (1989), suggesting that variability of ichnofabric reflects fluctuation of bottom sediment oxygenation. According to this model, the decrease of diversity and penetration depth of burrows reflects decreasing oxygen content, leading to progressive elimination of shallower tiers.

In the deposits studied, the ichnofabric recording the lowest oxygenation level consists of cryptobioturbation that persisted in bottom sediment as long as any oxygen was available (Bottjer and Savrda, 1993; Behl, 1995). In their oxygen-related biofacies model, Savrda and Bottjer (1991) refer this kind of deposit to a quasi-anaerobic biofacies, characterized by an oxygen content below $0.1 \mathrm{ml} / / \mathrm{O}_{2}$ (suboxic conditions). Truly anoxic conditions $\left(0 \mathrm{ml} / / \mathrm{O}_{2}\right)$, precluding development of any fauna (anaerobic biofacies - Savrda and Bottjer, 1991) might have existed in relatively short periods, leading to deposition of layers, up to $1 \mathrm{~cm}$ thick, of non-bioturbated clays. These, however, could also result from rapid deposition of relatively thick clay blankets (cf. smothered bottom in: Brett, 1983), without changing of oxygen content. If sediment layers were deposited under extremely poorly oxygenated conditions and were thicker than the depth of meiofaunal bioturbation (affecting the upper few millimetres of sediment) only the upper part of them would be reworked whereas, in the lower part, undisturbed primary fabric would be preserved (Savrda et al., 1984; Nittrouer et al., 1998). The most diverse trace fossil association, consisting of representatives of all ichnofabric tiers, reflects temporary improvements of oxygenation. The occurrence of this association within tempestite deposits suggests that reoxygenation events were the result of the water column mixing by storm-generated bottom currents, although the influence of other factors, such as turnover by regular wind shear or decrease of oxygen consumption linked with the lower surface productivity, cannot be excluded. Taking into account the low diversity of trace fossils, conditions prevailing in the bottom sediment during reoxygenation episodes should be defined as dysoxic.

Reoxygenation of bottom water could also lead to colonization of the sea-floor by the bivalve Bositra, forming bedding-plane accumulations in the mudstones. The significant amount of articulated specimens in "butterfly position" in these accumulations suggests that they likely represent episodes of temporal colonization followed by mass mortality rather than rapid burial by thick mud blankets (smothered bottom/obrution beds - Brett, 1983; Brett and Seilacher, 1991), as in the latter case shells should be preserved in the life position with closed valves (Brett and Allison, 1998). Bedding-plane accumulations of epibenthic fauna, occurring within laminated black shales, are characteristic feature of an exaerobic biofacies, defined by Savrda and Bottjer (1987) and interpreted as a record of short-lived reoxygenation episodes in a generally anoxic environment (Savrda and Bottjer, 1991). However, in this concept a sharp redox potential discontinuity (RPD) is postulated, situated directly at the sediment-water interface, precluding the establishment of a burrowing infauna, whereas in the deposits studied bioturbation is common. Thus, the observed accumulations of the bivalve Bositra reflect rather temporary oxygenation improvements within suboxic rather than in truly anoxic environment as in the case of an exaerobic biofacies. Small endobenthic bivalves (nuculids and nuculanids), found occasionally in the mudstones, seem to be single specimens brought in from shallower zones during storms. Thanks to their high tolerance of low oxygen levels they survived some time in the new setting, though decreasing oxygenation of the sea-floor prevented development of a denser population.

An alternative explanation of benthic association variations in oxygen-restricted environments was proposed by Sageman et al. (1991), who emphasize the role of the oxygenation gradient at the sediment-water interface (benthic boundary vs. unbounded biofacies). In their biofacies Type 1, constituting the end member of a redox gradient continuum, the redox boundary is located at some depth within the substrate, allowing colonization of the sediment by a benthic infauna. In the second end member - biofacies Type 2, the redox boundary is located at the sediment-water interface, making the bottom sediment uninhabitable, except for a low-oxygen tolerant epifauna. In this case, fluctuations of the chemical boundary may lead either to mass mortality of benthic fauna, if it extends above the sea-floor, or to brief colonization episodes, if it moves below the surface. The benthic faunal association from the deposits studied suggests bottom conditions similar to a Type 2 environment. 
The redox boundary, separating anoxic and dysoxic zones, was located probably just below the sediment-water interface. This enabled colonization of the sediment by organisms highly tolerant of low oxygen levels, including a meiofauna that reworked the uppermost part of the substrate and some infaunal, chemosymbiotic animals, producing pyritized burrows and Trichichnus. The sea-floor could have been inhabited by scattered epibenthic bivalves Bositra, occurring now as individual specimens dispersed in the mudstone. Temporary improvements of bottom oxygenation caused a downward shift of the redox boundary and establishment of conditions typical of a Type 1 environment with higher dysoxic conditions prevailing on the sea-floor and within the sediment. This resulted in increased depth of burrowing and development of a more diverse, tiered trace fossil association as well as colonization of the sea-floor by a large population of the bivalve Bositra. A subsequent decrease in oxygen content in both sediment and bottom water led again to upward shift of the chemical boundary, causing a decline in burrowers that demanded higher oxygen levels, and to diminishing of the epibenthic population. The possible brief extensions of this boundary above the sediment-water interface might have resulted in the extinction of epifaunal bivalves and the disappearance of bioturbation.

To sum up - regardless of which model would be applied the bottom conditions should be defined as poorly oxygenated (suboxic = lower dysoxic), with temporary improvements in oxygenation to higher dysoxic levels. In the model of Savrda and Bottjer (1991) this would result in alternation of quasi-anaerobic (in places anaerobic) and dysaerobic biofacies. Using the terminology proposed by Wignall and Hallam (1991; Wignall, 1994) this corresponds to the poikiloaerobic variety of biofacies 4 , characterized by intercalation of shelly and bioturbated laminae with laminae devoid of benthos and traces of its activity. The scheme of Sageman et al. (1991) describes such variability as an alternation of Type 1 and Type 2 conditions, linked to fluctuation of the redox boundary.

\section{CONCLUSIONS}

This study presents the first detailed sedimentological analysis of laminated mudstones of the Ore-Bearing Częstochowa Clay Formation combined with palaeoecological characterization of the bottom conditions. This shows that a key role in their deposition was played by bottom currents generated by frequent storms. These storms were responsible for redistribution of significant amounts of sediment from shallower areas and improvement of the sea-floor oxygenation by mixing of the water column.

The mudstones studied were deposited in a marginal part of a shallow epicontinental sea. The depositional site was located below storm wave base and the background sedimentation was dominated by suspension settling through the water column; however, sediment deposited in this way is volumetrically minor. Most of the lamination types described record storm events that repeatedly affected the sea-floor. Sediment was brought in by fine-grained suspension currents moving near the bottom, which transported the lower portion as bedload. These currents intermittently reworked deposited material, winnowing the finest particles and redepositing the coarsest material in form of starved ripples. The currents may have been generated as wave-induced turbidity currents, which carried suspended sediment in the form of fluid mud layers. The type and thickness of event laminae reflect the intensity of storm processes. The source area of storm-derived material was most likely a shallow, nearshore zone. Alternatively, sediment could be also supplied from intrabasinal swells, resulting from synsedimentary tectonics.

Conditions on the sea-floor were restricted due to the low oxygenation of both sediment and bottom water. This led to development of quasi-anaerobic biofacies, which changed intermittently during reoxygeantion events to dysaerobic biofacies. These events were linked most likely with water column mixing during storms, although other processes increasing oxygenation cannot be excluded. Oxygenation rises were accompanied by the shift of redox boundary from the sediment-water interface into the sediment, enabling the development of a tiered ichnofabric. Probably brief anoxic periods, during which the redox boundary extended above the sediment-water interface, may have led to the mass mortality of the epifaunal bivalve Bositra, colonizing the sea-floor during reoxygenation events.

The present study demonstrates the value of microstructural analysis in environmental studies of fine-grained rocks and reinforces the evidence that mudstones can be deposited by current activity. It points to the important role of bedload transport in the deposition of the mudstones studied and to the significant share of wave-induced fluid mud flows in sediment derivation. This interpretation of changeable bottom conditions with possibly brief anoxic events contributes to the general palaeoecological interpretation of the Ore-Bearing Częstochowa Clay Formation. The study constitutes a good starting point for sedimentological analyses of other deposits of the ore-bearing clays, showing different grades of bioturbation, and to the reconstruction of lithofacies distribution within the sedimentary basin.

Acknowledgements. The authoress would like to thank the reviewers N. O'Brien, J. Schieber and A. Wetzel for their constructive comments and many useful remarks, which greatly improved the final version of the manuscript. T. Peryt, the journal editor, is thanked for final editing of the manuscript, and the managements of the brickyards in Ogrodzieniec and Blanowice are thanked for providing access to their workings. The research was financed by the Institute of Geology, University of Warsaw.

\section{REFERENCES}

Aigner T. (1985) Storm depositional systems: dynamic stratigraphy in modern and ancient shallow-marine sequences. Lecture Notes in Earth Sciences, 3: 1-174.

Barski M. (2012) Dinoflagellate cysts from neptunian dykes in the Middle Jurassic of Poland - a stratigraphical approach. Revue of Palaeobotany and Palynology, 169: 38-47.
Barski M., Dembicz K., Praszkier T. (2004) Biostratigraphy and the Mid-Jurassic environment from the Ogrodzieniec quarry (in Polish with English summary). Tomy Jurajskie, 2: 61-68.

BehI R.J. (1995) Sedimentary facies and sedimentology of the Late Quaternary Santa Barbara Basin, Site 893. Proceedings of the Ocean Drilling Program, Scientific Results, 146: 295-308. 
Bottjer D.J., Savrda C.E. (1993) Oxygen-related mudrock biofacies. In: Sedimentology Review, 1 (ed. V.P. Wright): 92-102. Blackwell Scientific Publications.

Bromley R.G., Ekdale A.A. (1984) Chondrites: a trace fossil indicator of anoxia in sediments. Science, 224: 872-874.

Brett C.E. (1983) Sedimentology, facies and depositional environments of the Rochester Shale (Silurian; Wenlokian) in western New York and Ontario. Journal of Sedimentary Petrology, 53 (3): 947-971.

Brett C.E., Allison P.A. (1998) Paleontological approaches to the environmental interpretation of marine mudrocks. In: Shales and Mudstones, 1: Basin Studies, Sedimentology and Paleontology (eds. J. Schieber, W. Zimmerle and P.S. Sethi): 301-349. Schweizerbart'sche Verlagsbuchhandlung, Stuttgart.

Brett C.E., Seilacher A. (1991) Fossils Lagerstätten: a taphonomic consequence of event sedimentation. In: Cycles and Events in Stratigraphy (eds. G. Einsele, W. Ricken and A. Seilacher): 283-297. Springer-Verlag, Berlin, Heidelberg.

Dadlez R. (1989) Epicontinental Permian and Mesozoic basins in Poland (in Polish with English summary). Kwartalnik Geologiczny, 33 (2): 175-198.

Dadlez R., Marek S., Pokorski J., eds. (2000) Geological map of Poland without Cainozoic deposits, 1:1 000 000. Państwowy Instytut Geologiczny, Warszawa.

Dayczak-Calikowska K. (1997) Jura środkowa: sedymentacja, paleogeografia i paleotektonika. Prace Państwowego Instytutu Geologicznego, 153: 269-282.

Dayczak-Calikowska K., Kopik J. (1973) Jura środkowa. In: Budowa Geologiczna Polski. Stratygrafia, 1. Mezozoik, cz. 2: 237-324. Wydawnictwa Geologiczne, Warszawa.

Dayczak-Calikowska K., Moryc W. (1988) Evolution of sedimentary basin and palaeotectonics of the Middle Jurassic in Poland (in Polish with English summary). Kwartalnik Geologiczny, 32 (1): 117-136.

Droser M.L., Bottjer D.J. (1986) A semiquantitative field classification of ichnofabric. Journal of Sedimentary Research, 56 (4): 558-559.

Einsele G., Seilacher A. (1991) Distinction of tempestites and turbidites. In: Cycles and Events in Stratigraphy (eds. G. Einsele, W. Ricken and A. Seilacher): 377-382. Springer-Verlag, Berlin, Heidelberg.

Fain A.M.V., Ogston A.S., Sternberg R.W. (2007) Sediment transport event analysis on the western Adriatic continental shelf. Continental Shelf Research, 27: 431-451.

Feldman-Olszewska A. (1997) Depositional architecture of the Polish epicontinental Middle Jurassic basin. Geological Quarterly, 41 (4): 491-508.

Feldman-Olszewska A. (1998) Palaeogeographical map of Middle Bathonian Bremeri zone. In: Palaeogeographical Atlas of the Epicontinental Permian and Mesozoic in Poland (eds. R. Dadlez, S. Marek and J. Pokorski): pl. 45. Państwowy Instytut Geologiczny, Warszawa.

Futterer E. (1978) Hydrodynamic behaviour of biogenic particles. Neues Jahrbuch für Geologie und Paläontologie Abhandlungen, 157: 37-42.

Garbowska J., Łącka B., Pazdro O. (1978) Interrelation between microfauna and nature of Dogger deposits of the Częstochowa Jura (Poland). Acta Geologica Polonica, 23 (1): 89-105.

Gedl P., Boczarowski A., Kaim A., Kędzierski M., Leonowicz P., Smoleń J., Szczepanik P., Witkowska M. (2006a) Field Trip B1 - Biostratigraphical framework from Bajocian to Oxfordian. Stop B1.5 - Sowa's and Gliński's clay pits (uppermost Bajocian-lowermost Bathonian). Lithology, fossil assemblages and palaeoenvironment. In: Jurassic of Poland and Adjacent Slovakian Carpathians (eds. A. Wierzbowski et al.), Field Trip Guidebook: 151-152. 7th International Congress on the Jurassic System, September 6-18, 2006, Kraków, Poland.

Gedl P., Boczarowski A., Kaim A., Kędzierski M., Leonowicz P., Smoleń J., Szczepanik P., Witkowska M. (2006b) Field Trip B1 - Biostratigraphical framework from Bajocian to Oxfordian. Stop B1.6 - Leszczyński's clay pit (Lower Bathonian). Lithology, fossil assemblages and palaeoenvironment. In: Jurassic of Poland and Adjacent Slovakian Carpathians (eds. A. Wierzbowski et al.), Field Trip Guidebook: 153-154. 7th International Congress on the Jurassic System, September 6-18, 2006, Kraków, Poland.

Gedl P., Boczarowski A., Dudek T., Kaim A., Kędzierski M., Leonowicz P., Smoleń J., Szczepanik P., Witkowska M., Ziaja J. (2006c) Field Trip B1 - Biostratigraphical framework from Bajocian to Oxfordian. Stop B1.7 - Gnaszyn clay pit (Middle Bathonian-lowermost Upper Bathonian). Lithology, fossil assemblages and palaeoenvironment. In: Jurassic of Poland and Adjacent Slovakian Carpathians (eds. A. Wierzbowski et al.), Field Trip Guidebook: 155-156. 7th International Congress on the Jurassic System, September 6-18, 2006, Kraków, Poland.

Hill P.R. (1984) Facies and sequence analysis of Nova Scotian Slope muds: turbidite vs "hemipelagic" deposition. Geological Society Special Publications, 15: 311-318.

Hiscott R.N. (2003) Grading, graded bedding. In: Encyclopedia of Sediments and Sedimentary Rocks (ed. G.V. Middleton): 333-335. Kluwer Academic Publishers, Dordrecht.

Jarosińska U. (2000) Metoda utwardzania próbek osadów spoistych pobranych w stanie nienaruszonym do sporządzania średnioformatowych płytek cienkich. Przegląd Geologiczny, $\mathbf{4 8}$ (9): 787-789.

Kopik J. (1997) Jura środkowa: formalne i nieformalne jednostki stratygraficzne - Jura Polska. Prace Państwowego Instytutu Geologicznego, 153: 263-264.

Kopik J. (1998) Lower and Middle Jurassic of the north-eastern margin of the Upper Silesian Coal Basin (in Polish with English summary). Biuletyn Państwowego Instytutu Geologicznego, 378: $67-129$.

Kuenen Ph.H. (1966) Experimental turbidite lamination in a circular flume. Journal of Geology, 74 (5): 523-545.

Kutek J. (1994) Jurassic tectonic events in south-eastern cratonic Poland. Acta Geologica Polonica, 44 (3-4): 167-221.

Leonowicz P. (2012) Sedimentology and Ichnology of Bathonian (Middle Jurassic) ore-bearing clays at Gnaszyn, Kraków-Silesia Homocline, Poland. Acta Geologica Polonica, 62 (3): 281-296.

Lobza V., Schieber J. (1999) Biogenic sedimentary structures produced by worms in soupy, soft muds: observations from the Chattanooga Shale (Upper Devonian) and experiments. Journal of Sedimentary Research, 69 (5): 1041-1049.

Marynowski L., Zatoń M., Simoneit B.R.T., Otto A., Jędrysek M.O., Grelowski C., Kurkiewicz S. (2007) Compositions, sources and depositional environments of organic matter from the Middle Jurassic clays of Poland. Applied Geochemistry, 22: 2456-2485.

Matyja B.A., Wierzbowski A. (2000) Ammonites and stratigraphy of the uppermost Bajocian and Lower Bathonian between Częstochowa and Wieluń, Central Poland. Acta Geologica Polonica, 50 (2): 191-209.

Matyja B.A., Wierzbowski A. (2006) Field Trip B1 Biostratigraphical framework from Bajocian to Oxfordian. Stop B1.5 - Sowa's and Gliński's clay pits (uppermost Bajocian-lowermost Bathonian). Ammonite biostratigraphy. In: Jurassic of Poland and Adjacent Slovakian Carpathians (eds. A. Wierzbowski et al.), Field Trip Guidebook: 149-151. 7th International Congress on the Jurassic System, September 6-18, 2006, Kraków, Poland.

McBride E.F., Picard M.D. (1991) Facies implications of Trichichnus and Chondrites in turbidites and hemipelagites, Marnoso-arenacea formation (Miocene), Northern Apennines, Italy. Palaios, 6: 281-290.

McBride E.F., Shepherd R.G., Crawley R.A. (1975) Origin of parallel, near-horizontal laminae by migration of bed forms in a small flume. Journal of Sedimentary Petrology, 45 (1): 132-139.

Merta T., Drewniak A. (1998) Lithology and depositional environment of the Bathonian clays. In: Mellem- $\varnothing v$ re Jura i Polen. EEP-1995 projekt: Det polske Mellem-Øvre Epikratoniske Bassin, Stratigrafi, Facies og Bassin Historie. Program Østeuropa. Danmarks og Grønlands Geologiske Undersøgelse Rapport 1998/14 (eds. N.E. Poulsen et al.): 25-41. 
Myrow P.M. (1992) Bypass-zone tempestite facies model and proximality trends for an ancient muddy shoreline and shelf. Journal of Sedimentary Petrology, 62: 99-115.

Nittrouer C.A., Lopez G.R., Wright L.D., Bentley S.J., D’Andrea A.F., Friedrichs C.T., Craig N.I., Sommerfield C.K. (1998) Oceanographic processes and the preservation of sedimentary structure in Eckernförde Bay, Baltic Sea. Continental Shelf Research, 18: 1689-1714.

O'Brien N.R. (1996) Shale lamination and sedimentary processes Geological Society Special Publications, 116: 23-36.

O'Brien N.R., Brett C.E., Taylor W.L. (1994) Microfabric and taphonomic analysis in determining sedimentary processes in marine mudstones: example from Silurian of New York. Journal of Sedimentary Petrology, A64 (4): 847-852.

Parsons K.M., Brett C.E., Miller K.B. (1988) Taphonomy and depositional dynamics of Devonian shell-rich mudstones. Palaeogeography, Palaeoclimatology, Palaeoecology, 63: 109-139.

Pazdrowa O. (1967) The Bathonian microfauna from the vicinity of Ogrodzieniec. Exposure at the Ogrodzieniec brick-yard. Biuletyn Instytutu Geologicznego, 211: 146-164.

Pedersen G.K. (1985) Thin, fine-grained storm layers in a muddy shelf sequence: an example from the Lower Jurassic in the Stenlille 1 well, Denmark. Journal of Geological Society, 142 357-374.

Pemberton S.G., Frey R.W. (1982) Trace fossil nomenclature and the Planolites-Palaeophycus dilemma. Journal of Paleontology, 56 (4): 843-881.

Pemberton S.G., Spila M., Pulham A.J., Saunders T., MacEachern J.A., Robbins D., Sinclair I.K. (2001) Ichnology and sedimentology of shallow to marginal marine systems: Ben Nevis and Avalon Reservoirs, Jeanne d'Arc Basin. Geological Association of Canada, Short Course Notes, 15: 1-343.

Pemberton S.G., MacEachern J.A., Gingras M.K., Saunders T.D.A. (2008) Biogenic chaos: cryptobioturbation and the work of sedimentologically friendly organisms. Palaeogeography, Palaeoclimatology, Palaeoecology, 270: 273-279.

Pieńkowski G., Schudack M.E. (co-ordinators), Bosák P., Enay R., Feldman-Olszewska A., Golonka J., Gutowski J., Herngreen G.F.W., Jordan P., Krobicki M., Lathuiliere B., Leinfelder R.R., Michalík J., Mönnig E., Noe-Nygaard N., Pálfy J., Pint A., Rasser M.W., Reisdorf A.G., Schmid D.U., Schweigert G., Surlyk F., Wetzel A., Wong T.E. (2008). Jurassic. In: The Geology of Central Europe, 2. Mesozoic and Cenozoic (ed. T. McCann): 823-922. Geological Society of London.

Piper D.J.W. (1972) Turbidite origin of some laminated mudstones. Geological Magazine, 109 (2): 115-126.

Pratt L.M. (1984) Influence of paleoenvironmental factors on preservation of organic matter in Middle Cretaceous Greenhorn Formation, Pueblo, Colorado. AAPG Bulletin, 68 (9): 1146-1159.

Reineck H.E., Singh I.B. (1972) Genesis of laminated sand and graded rhythmites in storm-sand layers of shelf mud. Sedimentology, 18: 123-128.

Różycki S.Z. (1953) Górny dogger i dolny malm Jury Krakowsko-Częstochowskiej. Prace Instytutu Geologicznego, 17: 1-412.

Sageman B.B. (1989) The benthic boundary biofacies model Hartland Shale Member, Greenhorn Formation (Cenomanian), Western Interior, North America. Palaeogeography, Palaeoclimatology, Palaeoecology, 74: 87-110.

Sageman B.B., Wignall P.B., Kauffman E.G. (1991) Biofacies models for oxygen-deficient facies in epicontinental seas: too for paleoenvironmental analysis. In: Cycles and Events in Stratigraphy (eds. G. Einsele, W. Ricken, A. Seilacher): 542-564. Springer-Verlag, Berlin, Heidelberg.

Salamon M.A., Zatoń M. (2007) A diverse crinoid fauna from the Middle Jurassic (Upper Bajocian - Callovian) of the Polish Jura Chain and Holy Cross Mountains (south-central Poland). Swiss Journal of Geosciences, 100: 153-164.
Savrda C.E., Bottjer D.J. (1987) The exaerobic zone, a new oxygen-deficient marine biofacies. Nature, 327: 54-56.

Savrda C.E., Bottjer D.J. (1989) Trace-fossil model for reconstructing oxygenation histories of ancient marine bottom waters: application to Upper Cretaceous Niobara Formation, Colorado. Palaeogeography, Palaeoclimatology, Palaeoecology, 74: 49-74.

Savrda C.E., Bottjer D.J. (1991) Oxygen-related biofacies in marine strata: an overview and update. Geological Society Special Publications, 58: 201-219.

Savrda C.E., Bottjer D.J., Gorsline D.S. (1984) Development of a comprehensive oxygen-deficient marine biofacies model: evidence from Santa Monica, San Pedro and Santa Barbara Basins, California Continental Borderland. AAPG Bulletin, 68 (9): 1179-1192.

Schieber J. (1990) Significance of styles of epicontinental shale sedimentation in the Belt basin, Mid-Proterozoic of Montana, U.S.A. Sedimentary Geology, 69: 297-312.

Schieber J. (1994) Reflection of deep vs shallow water deposition by small scale sedimentary features and microfabrics of the Chattanooga Shale in Tennessee. Canadian Society of Petroleum Geologists Memoir, 17: 773-784.

Schieber J. (1999) Distribution and deposition of mudstone facies in the Upper Devonian Sonyea Group of New York. Journal of Sedimentary Research, 69 (4): 909-925.

Schieber J. (2003) Simple gifts and buried treasures - implications of finding bioturbation and erosion surfaces in black shales. Sedimentary Record, 1 (2): 4-8.

Schieber J., Yawar Z. (2009) A new twist on mud deposition - mud ripples in experiment and rock record. Sedimentary Record, 7 (2): 4-8.

Schieber J., Southard J., Thaisen K. (2007) Accretion of mudstone beds from migrating floccule ripples. Science, 318: 1760-1763.

Seilacher A., Seilacher E. (1994). Bivalvian trace fossils: a lesson from actuopaleontology. Courier Forschungsinstitut Senckenberg, 169: 5-15

Smoleń J. (2006) Palaeoenvironmental significance of the foraminiferal assemblages from the Middle Jurassic deposits of the Częstochowa area. Volumina Jurassica, 4: 136.

Sternberg R.W., Cacchione D.A., Paulson T.B., Kineke G.C., Drake D.E. (1996) Observations of sediment transport on the Amazon subaqueous delta. Continental Shelf Research, 16: 697-715.

Stow D.A.V., Bowen A.J. (1980) A physical model for the transport and sorting of fine-grained sediment by turbidity currents. Sedimentology, 27: 31-46.

Stow D.A.V., Piper D.J.W. (1984) Deep-water fine-grained sediments: facies models. Geological Society Special Publications, 15: 611-646.

Stow D.A.V., Shanmugam G. (1980) Sequence of structures in fine-grained turbidites: comparison of recent deep-sea and ancient flysch sediments. Sedimentary Geology, 25: 23-42.

Szczepanik P., Sawłowicz Z. (2008) Potential ZnS fossilization of gastropods (Middle Jurassic claystones from Central Poland). Naturwissenschaften, 95: 869-876.

Szczepanik P., Witkowska M., Sawłowicz Z. (2005) Warunki depozycji środkowojurajskich iłów rudonośnych z Ogrodzieńca (Wyżyna Krakowsko-Częstochowska) - wstępne wyniki badań geochemicznych. Tomy Jurajskie, 3: 131-132.

Szczepanik P., Witkowska M., Sawłowicz Z. (2007) Geochemistry of Middle Jurassic mudstones (Kraków-Częstochowa area, southern Poland): interpretation of the depositional redox conditions. Geological Quarterly, 51 (1): 57-66.

Traykovski P., Geyer W.R., Irish J.D., Lynch J.F. (2000) The role of wave-induced density-driven fluid mud flows for cross-shelf transport on the Eel River continental shelf. Continental Shelf Research, 20: 2113-2140. 
Wignall P.B. (1989) Sedimentary dynamics of the Kimmeridge Clay: tempests and earthquakes. Journal of Geological Society, 146: 273-284.

Wignall P.B. (1994) Black Shales. Clarendon Press, Oxford.

Wignall P.B., Hallam A. (1991) Biofacies, stratigraphic distribution and depositional models of British onshore Jurassic black shales. Geological Society Special Publications, 58: 291-309.

Wright L.D., Friedrichs C.T. (2006) Gravity-driven sediment transport on continental shelves: a status report. Continental Shelf Research, 26: 2092-2107.

Zatoń M. (2007) Amonity z iłów rudonośnych (bajos-baton) Jury Polskiej. Unpubl. Ph.D. thesis. University of Silesia, Sosnowiec.

Zaton M. (2011) Diversity dynamics of ammonoids during the latest Bajocian and Bathonian (Middle Jurassic) in the epicratonic Polish Basin. Palaeobiodiversity and Palaeoenvironments, 91: 89-99.

Zatoń M., Taylor P.D. (2009) Middle Jurassic cyclostome bryozoans from the Polish Jura. Acta Palaeontologica Polonica, 54 (2): 267-288.
Zatoń M., Marynowski L., Bzowska G. (2006) Hiatus concretions from the ore-bearing clays of the Cracow-Częstochowa Upland (Polish Jura) (in Polish with English summary). Przegląd Geologiczny, 54 (2): 131-138.

Zatoń M., Marynowski L., Szczepanik P., Bond D.P.G., Wignall P.B. (2009) Redox conditions during sedimentation of the Middle Jurassic (Upper Bajocian-Bathonian) clays of the Polish Jura (south-central Poland). Facies, 55:103-114.

Zatoń M., Machocka S., Wilson M.A., Marynowski L., Taylor P.D. (2011) Origin and paleoecology of Middle Jurassic hiatus concretions from Poland. Facies, 57: 275-300.

Zatoń M., Kremer B., Marynowski L., Wilson M.A., Krawczyński W. (2012) Middle Jurassic (Bathonian) encrusted oncoids from the Polish Jura, southern Poland. Facies, 58: 57-77.

Ziegler P.A. (1990) Geological Atlas of Western and Central Europe. Shell Internationale Petroleum Maatschappij BV. 